\title{
Microencapsulation of Bioactive Ingredients for Their Delivery into Fermented Milk Products: A Review
}

\author{
Ruta Gruskiene ${ }^{1,+}$, Alma Bockuviene ${ }^{2,+}$ and Jolanta Sereikaite ${ }^{1, * \text { (D) }}$ \\ 1 Department of Chemistry and Bioengineering, Vilnius Gediminas Technical University, \\ 10223 Vilnius, Lithuania; ruta.gruskiene@vgtu.lt \\ 2 Department of Polymer Chemistry, Institute of Chemistry, Vilnius University, 01513 Vilnius, Lithuania; \\ burvytealma@gmail.com \\ * Correspondence: jolanta.sereikaite@vgtu.lt \\ + These authors contributed equally to this work.
}

Citation: Gruskiene, R.; Bockuviene, A.; Sereikaite, J. Microencapsulation of Bioactive Ingredients for Their Delivery into Fermented Milk Products: A Review. Molecules 2021, 26, 4601. https://doi.org/10.3390 /molecules26154601

Academic Editor: Dimitrios Bikiaris

Received: 17 June 2021

Accepted: 27 July 2021

Published: 29 July 2021

Publisher's Note: MDPI stays neutral with regard to jurisdictional claims in published maps and institutional affiliations.

Copyright: (c) 2021 by the authors. Licensee MDPI, Basel, Switzerland. This article is an open access article distributed under the terms and conditions of the Creative Commons Attribution (CC BY) license (https:// creativecommons.org/licenses/by/ $4.0 /)$
Abstract: The popularity and consumption of fermented milk products are growing. On the other hand, consumers are interested in health-promoting and functional foods. Fermented milk products are an excellent matrix for the incorporation of bioactive ingredients, making them functional foods. To overcome the instability or low solubility of many bioactive ingredients under various environmental conditions, the encapsulation approach was developed. This review analyzes the fortification of three fermented milk products, i.e., yogurt, cheese, and kefir with bioactive ingredients. The encapsulation methods and techniques alongside the encapsulant materials for carotenoids, phenolic compounds, omega-3, probiotics, and other micronutrients are discussed. The effect of encapsulation on the properties of bioactive ingredients themselves and on textural and sensory properties of fermented milk products is also presented.

Keywords: encapsulation; encapsulant material; yogurt; cheese; kefir; carotenoids; phenolics; probiotics; omega-3; micronutrients

\section{Introduction}

Nowadays, there is a growing consumer interest in products that promote health and well-being. The beneficial effect of fermented milk products has been well-known since ancient times. Their health benefits are attributed to the action and metabolites of lactic acid bacteria (LAB) as well as biologically active components of milk. In addition to $L A B$, the diverse set of microorganisms, including yeast, molds, and bacteria is used for the production of fermented milk products [1]. They can be divided into two large groups, i.e., fermented milks and cheeses. There is a great variety of fermented milks depending on a specific culture used for the fermentation, the type of raw material (cow, sheep, goat, mare, camel, or buffalo milk), and the geographic location [2]. Yogurt obtained by symbiotic cultures of Streptococcus thermophilus and Lactobacillus delbrueckii subsp. bulgaricus is the most popular fermented milk product all over the world. Yogurt based on Streptococcus thermophilus and all species of Lactobacillus, acidophilus milk, kefir, kumys, and cultured buttermilk are also known and popular among consumers [2,3]. Cheeses exhibit a very high diversity of composition and structure. According to the FAO/WHO Codex Alimentarius Commission, they are classified depending on the water content in the fat-free matter, fat content in the dry matter, and ripening [1]. Fermented milk products modulate the intestinal microbiota and suppress the growth of pathogens due to the action of metabolites, such as lactic acid and bacteriocins accumulated during the fermentation process. There are data that the consumption of fermented milk products is associated with a lower risk of developing stroke, cardiovascular disease, and type 2 diabetes mellitus [3,4] Recently, the possible anti-cancer effect of kefir, especially in the case of intestinal and colorectal cancer, has been announced [5]. 
Despite their own health benefits, fermented milk products are an excellent matrix for the incorporation of bioactive ingredients, making them true functional foods [3]. To provide functional characteristics, bioactive compounds and probiotics are largely investigated. However, many of them are unstable under the changes of various environmental conditions such as temperature, $\mathrm{pH}$, and light; exhibit a residual taste, limiting their application; or have low solubility [6]. To overcome these drawbacks, the strategy of nano/microencapsulation of bioactive ingredients was developed (Figure 1). Encapsulation is the method when an active agent is entrapped within another substance. The active agent can be also called the core or payload. The encapsulating substance can be termed the shell, wall, matrix, encapsulant, or carrier. The active compound can be found in the interior of the shell-like structure of the encapsulating material or can be interspersed within the matrix. The carrier materials act as a physicochemical barrier against environmental conditions and improve the physicochemical and biological characteristics of the encapsulated active agents. The dimensions of encapsulated product can be at the scale of nano- and micrometers [7-9]. Nanoscale technology has the advantages compared to microencapsulation. Nanocapsules have higher surface area. That may lead to the improvement in bioavailability and solubility of bioactive ingredients. Moreover, lower scale capsules are more preferable in terms of sensory properties of food products. As an example, nanoemulsions having the size of droplets less than $100 \mathrm{~nm}$ are optically transparent. That is very important for the application in the beverage industry $[10,11]$.
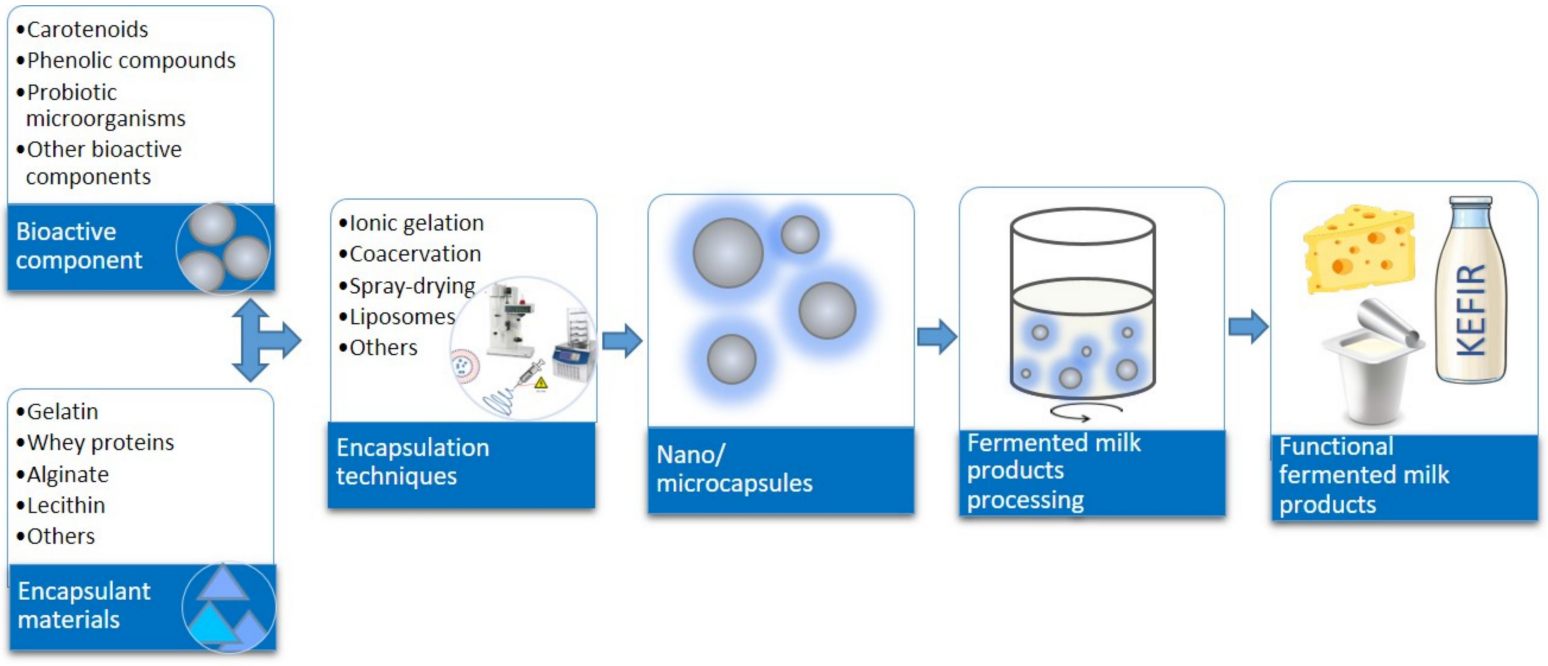

Figure 1. Schematic representation of the delivery of encapsulated bioactive ingredients into fermented milk products.

The choice of encapsulation techniques and delivery system depends not only on the physical and chemical properties of the bioactive compounds but also on the end product characteristics. Encapsulated and delivered bioactive compounds have to not alter undesirably the appearance, texture, or mouthfeel of the end product. Delivery systems of bioactive compounds have to be easily scaled up, economic, and prepared from ingredients that are acceptable in foods $[12,13]$.

Herein, we review the nano/micro encapsulation methods and materials used for the delivery of bioactive ingredients into the most popular fermented milk products, i.e., yogurt, kefir, and cheese. The effect of encapsulated ingredients on the health-promoting and sensory properties of products is discussed as well.

\section{Yogurt Fortification with Nano/Microencapsulated Bioactive Ingredients}

\subsection{Carotenoids and Carotenoids Containing Components}

Carotenoids are a group of isoprenoid compounds biosynthesized by all photosynthetic organisms and many bacteria and fungi. They are natural pigments and have an intense red/orange/yellow color. Most animals (including humans) are unable to synthe- 
size carotenoids in their bodies. Humans obtain carotenoids from the diet mainly from fruits and vegetable-derived foods. The consumption of carotenoids is associated with health benefits, i.e., the lower risk of cancer, cardiovascular diseases, age-related macular degeneration and type 2 diabetes, and the enhanced immune system function. Moreover, some of them have provitamin A activity. Therefore, the normal daily dietary intake of carotenoids is essential having in mind their role in retaining human body function [14-16]. In their structure, carotenoids have a polyene system containing conjugated double bonds and can act as single oxygen quenchers and free radical scavengers. However, due to the double bonds in their structure, carotenoids are susceptible to heat, oxygen, and temperature, and easily undergo the isomerization and degradation [17].

The fortification of foods with carotenoids, including yogurt, can ensure their daily intake. Table 1 summarizes recently published findings concerning carotenoids delivery systems into yogurt [18-30]. As seen, pure carotenoids or the extracts from fruits and vegetables are used for encapsulation. Palm oil rich in carotenoids can also be encapsulated and entrapped into yogurt. Shrimp waste can serve as a source of astaxanthin for the application in the dairy industry. In crustaceans, carotenoids occur due to their absorption from the diet, and astaxanthin is the principal one [31]. As seen from Table 1, various encapsulation systems are used, i.e., emulsion-based, including solid lipid nanoparticles, biopolymer-based, including molecular inclusion complexes, surfactant-based (liposomes), and freeze- and spray-drying ones [19-30]. In addition, a modern electro-spinning technique was applied for the tomato peel extract encapsulation to use the prepared nanofibers in yogurt [18]. The encapsulation of pure carotenoid or their extracts ensures more stable yogurt coloration due to the higher carotenoid retention compared to the free form $[20-23,28]$. The addition of encapsulated carotenoids increases the functionality of yogurt, including the increase of their antioxidant activity [18]. However, there are only a few works, in which the release and bioaccessibility of encapsulated carotenoids added into yogurt are analyzed $[25,29,30]$. In general, the sensory acceptability of yogurt fortified with encapsulated carotenoids is similar or even higher compared to yogurt fortified with the free form of carotenoids or without fortification $[18,19,23,24,26,28]$. However, the consumers perceived the differences in the taste and mouthfeel of yogurt supplemented with astaxanthin-loaded alginate-chitosan beads although the appearance, color, and aroma of the yogurt were not changed [27]. 
Table 1. Encapsulation of carotenoids and carotenoids containing components for yogurt's fortification.

\begin{tabular}{|c|c|c|c|c|}
\hline $\begin{array}{l}\text { Bioactive } \\
\text { Component }\end{array}$ & $\begin{array}{l}\text { Encapsulation } \\
\text { Techniques and } \\
\text { Systems }\end{array}$ & Encapsulant Materials & Observations & References \\
\hline $\begin{array}{l}\text { Tomato peel } \\
\text { extract }\end{array}$ & Electrospinning & Zein, gelatin & $\begin{array}{c}\text { Similar properties to control yogurt } \\
\text { sample in terms of yogurt acidity, } \mathrm{pH} \text {, } \\
\text { syneresis, and viscosity. The increase of } \\
\text { yogurt free radical scavenging activity } \\
\text { by } 40-60 \% \text {. }\end{array}$ & [18] \\
\hline $\begin{array}{l}\text { Red pepper waste } \\
\text { extract }\end{array}$ & $\begin{array}{l}\text { Freeze drying, } \\
\text { spray drying }\end{array}$ & Whey proteins & $\begin{array}{l}\text { Fortified yogurt showed higher sensory } \\
\text { and general acceptability scores } \\
\text { compared to control sample. }\end{array}$ & [19] \\
\hline $\begin{array}{c}\text { Red bell pepper } \\
\text { extract }\end{array}$ & $\begin{array}{l}\text { Inclusion } \\
\text { complexation by } \\
\text { ultrasonic } \\
\text { homogenization }\end{array}$ & $\beta$-Cyclodextrin & $\begin{array}{l}\text { A mean particle diameter was } 562 \mathrm{~nm} \text {. } \\
\text { The prepared complexes can simulate } \\
\text { the color of papaya flavors. The higher } \\
\text { stability of color was observed for } \\
\text { yogurt colored with inclusion } \\
\text { complexes comparing with yogurt } \\
\text { colored with crude extract. }\end{array}$ & [20] \\
\hline $\begin{array}{l}\text { Cantaloupe } \\
\text { melon extract }\end{array}$ & $\begin{array}{l}\text { Emulsification in } \\
\text { O/W followed by } \\
\text { lyophilization }\end{array}$ & $\begin{array}{c}\text { Gelatin as a wall } \\
\text { material }\end{array}$ & $\begin{array}{l}\text { The solubility of extract encapsulated in } \\
\text { gelatin (EG) was } 0.072 \mathrm{mg} / \mathrm{mL} \text {. EG gave } \\
\text { homogenous yellow coloration to } \\
\text { yogurt; staining was preserved over } 60 \\
\text { days. }\end{array}$ & [21] \\
\hline$\beta$-Carotene & $\begin{array}{l}\text { Spray-dried } \\
\text { emulsion followed } \\
\text { by fluidized bed } \\
\text { coating }\end{array}$ & $\begin{array}{l}\text { Maltodextrin or } \\
\text { sodium caseinate for } \\
\text { emulsification and } \\
\text { hydroxypropyl } \\
\text { cellulose for coating. }\end{array}$ & $\begin{array}{l}\text { Coated powders were used for yogurt } \\
\text { coloration. After } 4 \text { weeks of storage, the } \\
\text { changes of yogurt color were minimal. } \\
\text { Total color difference } \Delta \mathrm{E} \text { value was }<3 \text {. }\end{array}$ & [22] \\
\hline$\beta$-Carotene & $\begin{array}{l}\text { Multilamellar } \\
\text { liposomes obtained } \\
\text { by the hydration of } \\
\text { proliposomes }\end{array}$ & $\begin{array}{l}\text { Stabilized by the } \\
\text { mixture of xanthan and } \\
\text { guar gums. }\end{array}$ & $\begin{array}{l}\text { About } 90 \% \text { of the encapsulated } \\
\beta \text {-carotene was preserved after the } \\
\text { storage for } 95 \text { days at } 7-10^{\circ} \mathrm{C} \text {. } \\
\text { Liposomes were tested as colorant in } \\
\text { yogurt. Its texture was not affected by } \\
\text { the incorporation of the liposomes. }\end{array}$ & [23] \\
\hline$\beta$-Carotene & $\begin{array}{l}\text { Solid lipid } \\
\text { microparticles } \\
\quad(\text { SLM) }\end{array}$ & $\begin{array}{l}\text { Palm stearin as the } \\
\text { lipid phase and } \\
\text { hydrolyzed soy protein } \\
\text { isolate for particles } \\
\text { stabilization }\end{array}$ & $\begin{array}{l}\text { The average diameter of SLM was } 1.2 \\
\mu \mathrm{m} \text {. The amount of } 25 \mathrm{~g}(500 \mathrm{~mL}) \text { of } \\
\text { SLM was added to } 10 \mathrm{~L} \text { of yogurt. The } \\
\text { addition of SLM did not change the } \\
\text { physicochemical and rheological } \\
\text { characteristics of yogurt. Based on } \\
\text { sensory analysis, the average grade of } \\
\text { global acceptance was } 7.4 \text { ("liked it very } \\
\text { much") on the hedonic scale. }\end{array}$ & [24] \\
\hline$\beta$-Carotene & $\begin{array}{l}\text { Spray drying; } \\
\text { coacervation for } \\
\text { beads }\end{array}$ & $\begin{array}{l}\text { Maltodextrin for spray } \\
\text { drying } \\
\text { Chitosan and alginate } \\
\text { for beads }\end{array}$ & $\begin{array}{l}\text { In yogurt, spray-dried } \beta \text {-carotene } \\
\text { showed higher release and the } \\
\text { incorporation into micelle phase during } \\
\text { digestion than } \beta \text {-carotene encapsulated } \\
\text { in chitosan-alginate beads. }\end{array}$ & [25] \\
\hline
\end{tabular}


Table 1. Cont.

\begin{tabular}{|c|c|c|c|c|}
\hline $\begin{array}{l}\text { Bioactive } \\
\text { Component }\end{array}$ & $\begin{array}{l}\text { Encapsulation } \\
\text { Techniques and } \\
\text { Systems }\end{array}$ & Encapsulant Materials & Observations & References \\
\hline Zeaxanthin & $\begin{array}{l}\text { Nanoemulsion by } \\
\text { high-pressure } \\
\text { homogenization }\end{array}$ & $\begin{array}{l}\text { Zeaxanthin was } \\
\text { dispersed in chia seed } \\
\text { oil. Tween } 80 \text { for } \\
\text { emulsification. }\end{array}$ & $\begin{array}{l}\text { After } 28 \text { days of yogurt storage, } \\
\text { zeaxanthin retention was } 16.84 \% \text {. Higher } \\
\text { bioaccessibility as compared to } \\
\text { zeaxanthin nanoparticles. }\end{array}$ & [26] \\
\hline Zeaxanthin & Nanoparticles & $\begin{array}{l}\text { Cactus mucilage as a } \\
\text { wall material. } \\
\text { Zeaxanthin was } \\
\text { dispersed in chia seed } \\
\text { oil. }\end{array}$ & $\begin{array}{l}\text { After } 28 \text { days of yogurt storage, } \\
\text { zeaxanthin retention was } 22.31 \% \text {. The } \\
\text { incorporation of zeaxanthin nanoparticles } \\
\text { decreased the texture and viscosity and } \\
\text { increased the syneresis when compared to } \\
\text { the control yogurt. The changes were not } \\
\text { sensory perceived. }\end{array}$ & [26] \\
\hline Astaxanthin & $\begin{array}{l}\text { Beads prepared } \\
\text { using ultrasonic } \\
\text { atomizer }\end{array}$ & Alginate and chitosan & $\begin{array}{l}\text { The concentration of beads in yogurt was } \\
15 \%(w / w) \text {. No differences were observed } \\
\text { for the appearance, color, and aroma as } \\
\text { compared to control yogurt. Consumers } \\
\text { perceived differences in terms of taste, } \\
\text { mouthfeel, and overall liking attributes. }\end{array}$ & [27] \\
\hline $\begin{array}{l}\text { Lipid extract of } \\
\text { astaxanthin from } \\
\text { shrimp waste }\end{array}$ & $\begin{array}{l}\text { Complex } \\
\text { coacervation with } \\
\text { following freeze } \\
\text { drying. }\end{array}$ & $\begin{array}{l}\text { Gelatin and cashew } \\
\text { gum }\end{array}$ & $\begin{array}{l}\text { Coloring capacity of microcapsules was } \\
\text { compared to non-encapsulated lipid } \\
\text { extract. Both forms of astaxanthin yielded } \\
\text { the orange color of yogurt. Encapsulated } \\
\text { form showed more intense color. No } \\
\text { differences in odor between the yogurt } \\
\text { sample containing encapsulated lipid } \\
\text { extract and the sample containing } \\
\text { non-encapsulated lipid extract were } \\
\text { found. }\end{array}$ & [28] \\
\hline Palm oil & Coacervation & $\begin{array}{l}\text { Chitosan and car- } \\
\text { boxymethylcellulose }\end{array}$ & $\begin{array}{l}\text { Particles showed the ideal carotenoid } \\
\text { release in gastric fluid, but low release in } \\
\text { the intestinal fluid, which increased when } \\
\text { applied to yogurt. }\end{array}$ & [29] \\
\hline Palm oil & Ionic gelation & $\begin{array}{l}\text { Chitosan plus sodium } \\
\text { tripolyphosphate as a } \\
\text { cross-linker }\end{array}$ & $\begin{array}{l}\text { Particles showed high carotenoid release } \\
\text { in gastric fluid, but satisfactory release in } \\
\text { intestinal fluid. The release further } \\
\text { increased when the particles were added } \\
\text { to yogurt. }\end{array}$ & [29] \\
\hline Palm oil & $\begin{array}{l}\text { Coacervation } \\
\text { followed by } \\
\text { lyophilization }\end{array}$ & $\begin{array}{l}\text { Chitosan and xanthan; } \\
\text { chitosan and pectin }\end{array}$ & $\begin{array}{l}\text { Chitosan/xanthan microparticles applied } \\
\text { in yogurt released approximately } 50 \% \text { of } \\
\text { the content in the intestinal fluid. The } \\
\text { behavior of release was similar to the } \\
\text { desired one. The release of content from } \\
\text { chitosan/pectin microparticles was } \\
\text { slower. }\end{array}$ & {$[30]$} \\
\hline
\end{tabular}

\subsection{Phenolic Compounds (Phenolics) Containing Components}

Phenolics are a second large group of compounds delivered into yogurt in the encapsulated form. Phenolics are diverse in their structure and are classified into the following main classes, i.e., flavonoids, phenolic acids, coumarins, lignans, tannins, and stilbenes. They are secondary metabolites of plants, and usually, their extracts serve as a dietary source of phenolics. In recent years, they have received the attention due to the positive effects on human health. Phenolics have antioxidant, antimicrobial, and anti-inflammatory 
activities and show anticarcinogenic effects [31-33]. However, their instability in food, the bitter taste, and low bioavailability often limit their application.

The nano/microencapsulation approach facilitates the delivery of phenolics into various food matrices. For the encapsulation, mainly the extracts from various plants and fruits are used (Table 2). Surfactant-based encapsulation systems such as liposomes coated with chitosan or spray-dried coated liposomes and spray-drying method are preferred for yogurt fortification [34-38]. In addition, the particles are prepared by the coacervation [39], ionic gelation [40], and ultrasonication methods [41]. For yogurt enrichment with resveratrol, niosomes were evaluated [42]. These vesicles are formed by the self-assembly of non-ionic surfactants. Cholesterol is often used for their preparation. It is important for niosomes properties such as membrane permeability, rigidity, and encapsulation efficiency [43]. Since cholesterol has potential adverse health effects and is not suitable for functional foods, for resveratrol delivery, it was substituted by lauryl alcohol [42]. The addition of encapsulated extracts had no influence on the texture properties and color of yogurt independently on the encapsulation system. The antioxidant activity of yogurt increased or retained longer compared to the nonencapsulated form of the extracts [34-36,44].

Table 2. Encapsulation of phenolic compounds containing components for yogurt's fortification.

\begin{tabular}{|c|c|c|c|c|}
\hline $\begin{array}{l}\text { Bioactive } \\
\text { Component }\end{array}$ & $\begin{array}{l}\text { Encapsulation } \\
\text { Techniques } \\
\text { and Systems }\end{array}$ & Encapsulant Materials & Observations & References \\
\hline $\begin{array}{c}\text { Grape seed } \\
\text { extract }\end{array}$ & Spray drying & $\begin{array}{l}\text { Whey proteins and } \\
\text { gum arabic }\end{array}$ & $\begin{array}{l}\text { The addition of encapsulated grape seed extract } \\
\text { at the final concentration of } 1 \% \text { resulted in } \\
\text { similar sensory properties, viscosity, acidity, } \\
\text { water-holding capacity, and color compared to } \\
\text { the control. The antioxidant activity increased } \\
\text { four-fold. }\end{array}$ & [34] \\
\hline $\begin{array}{c}\text { Orange peel } \\
\text { extract }\end{array}$ & Coacervation & $\begin{array}{l}\text { Whey proteins and } \\
\text { gum arabic }\end{array}$ & $\begin{array}{c}\text { The negative influence on the physicochemical } \\
\text { and organoleptic properties of yogurt was not } \\
\text { observed. }\end{array}$ & [39] \\
\hline $\begin{array}{l}\text { Sour cherry } \\
\text { extract }\end{array}$ & $\begin{array}{l}\text { Spray-dried } \\
\text { coated } \\
\text { liposomes }\end{array}$ & $\begin{array}{l}\text { Lecithin for liposomes } \\
\text { preparation and } \\
\text { chitosan for their } \\
\text { coating. }\end{array}$ & $\begin{array}{l}\text { Liposomal powders (LP) were added to yogurt } \\
\text { with a ratio of } 5 \%(w / w) \text {. The addition of LP } \\
\text { did not change the color parameters of yogurt } \\
\text { up to } 14 \text { days of storage. Encapsulation } \\
\text { provided the stability of extract in terms of total } \\
\text { phenolic content and antioxidant capacity. }\end{array}$ & [35] \\
\hline Doum extract & $\begin{array}{l}\text { Coated } \\
\text { liposomes }\end{array}$ & $\begin{array}{l}\text { Lecithin for liposomes } \\
\text { preparation and } \\
\text { chitosan for their } \\
\text { coating. }\end{array}$ & $\begin{array}{l}\text { Naringenin was the main component of } \\
\text { extracted phenolics. Yogurt fortified with } 5 \% \text { of } \\
\text { liposome solution had similar characteristics } \\
\text { including the acidity, water-holding capacity, } \\
\text { and texture parameters as a control yogurt, but } \\
\text { the antioxidant activity was higher. The } \\
\text { addition of higher percentage of encapsulated } \\
\text { product affected markedly the functional } \\
\text { properties of yogurt. }\end{array}$ & [36] \\
\hline $\begin{array}{c}\text { Cocoa hull waste } \\
\text { extract }\end{array}$ & $\begin{array}{l}\text { Spray-dried } \\
\text { coated } \\
\text { liposomes }\end{array}$ & $\begin{array}{l}\text { Lecithin for liposomes } \\
\text { preparation and } \\
\text { chitosan for their } \\
\text { coating. }\end{array}$ & $\begin{array}{l}\text { For yogurt fortification, liposomes in two forms, } \\
\text { i.e., dispersion and sprayed-dried powders, } \\
\text { were used. The best results were found for the } \\
\text { powder form in terms of total phenolic } \\
\text { compounds and total antioxidant activity. }\end{array}$ & [37] \\
\hline
\end{tabular}


Table 2. Cont.

\begin{tabular}{|c|c|c|c|c|}
\hline $\begin{array}{l}\text { Bioactive } \\
\text { Component }\end{array}$ & $\begin{array}{l}\text { Encapsulation } \\
\text { Techniques } \\
\text { and Systems }\end{array}$ & Encapsulant Materials & Observations & References \\
\hline $\begin{array}{l}\text { Hibiscus calyx } \\
\text { extract }\end{array}$ & $\begin{array}{l}\text { Double } \\
\text { emulsion and } \\
\text { following } \\
\text { ionic gelation. }\end{array}$ & Rapeseed oil and pectin & $\begin{array}{l}\text { The extract is rich in anthocyanins. } \\
\text { Microparticles were obtained by } \\
\text { dripping-extrusion and atomization methods. } \\
\text { The microparticles were added to yogurt with a } \\
\text { ratio of } 20 \%(w / w) \text {. The yogurt supplemented } \\
\text { with microparticles obtained by atomization } \\
\text { had higher appearance acceptability, but the } \\
\text { retention of bioactive compounds was lower } \\
\text { comparing to dripping techniques. }\end{array}$ & [40] \\
\hline $\begin{array}{l}\text { Tartary } \\
\text { buckwheat } \\
\text { extract }\end{array}$ & $\begin{array}{l}\text { Beads were } \\
\text { prepared by } \\
\text { thermally- } \\
\text { induced } \\
\text { polymeriza- } \\
\text { tion of } \\
\text { proteins and } \\
\text { following } \\
\text { spray drying. }\end{array}$ & Whey proteins & $\begin{array}{l}\text { The extract is rich in rutin and quercetin. } \\
\text { Yogurt contained } 3 \%(w / w) \text { of beads. } \\
\text { Encapsulation masked the dark yellow color } \\
\text { and bitter taste of extract and protected } \\
\text { flavonoids from the gastric juice. }\end{array}$ & [45] \\
\hline $\begin{array}{l}\text { Olive leaves } \\
\text { extract }\end{array}$ & Nanoliposomes & $\begin{array}{l}\text { Lecithin and } \\
\text { cholesterol with the } \\
\text { ratio of } 4: 1 .\end{array}$ & $\begin{array}{l}\text { The extract is rich in oleuropein. The amount of } \\
100 \mathrm{~g} \text { yogurt was fortified with } 15 \mathrm{~g} \text { (containing } \\
10 \% \text { of phenolics) of nanoliposomes. No } \\
\text { changes in color and sensorial attributes were } \\
\text { observed. The antioxidant activity did not } \\
\text { change during the yogurt storage for } 21 \text { days. }\end{array}$ & [44] \\
\hline $\begin{array}{l}\text { Eggplant } \\
\text { (Solanum } \\
\text { melongena L.) bark } \\
\text { extract }\end{array}$ & Spray drying & Gum arabic & $\begin{array}{l}\text { The extract is rich in anthocyanins. The amount } \\
\text { of } 1,1.5 \text {, and } 2 \mathrm{~g} \text { of encapsulated and } \\
\text { nonencapsulated extract was added to } 100 \mathrm{~g} \text { of } \\
\text { yogurt. More than } 50 \% \text { of free anthocyanins } \\
\text { degraded in yogurt after } 20 \text { days of storage, } \\
\text { whereas encapsulated ones remained stable. } \\
\text { The decrease of antioxidant activity was slower } \\
\text { for yogurts fortified with the encapsulated form } \\
\text { of extract. }\end{array}$ & [38] \\
\hline Date palm pollen & $\begin{array}{l}\text { Nanocapsules } \\
\text { obtained by } \\
\text { ultrasonica- } \\
\text { tion }\end{array}$ & $\begin{array}{l}\text { Sodium caseinate and } \\
\text { lecithin }\end{array}$ & $\begin{array}{l}\text { The extract is rich in catechin. The size of } \\
\text { capsules was approximately in the range of } \\
200-300 \mathrm{~nm} \text {. The amount of pollen extract in } \\
\text { free and encapsulated form was } 0.75 \%(w / v) \text { of } \\
\text { milk. No color changes were observed for } \\
\text { yogurt fortified with encapsulated pollen } \\
\text { extract. It also scored the higher scores of } \\
\text { appearance and body and texture compared to } \\
\text { yogurt fortified with free extract. Overall, } \\
\text { sensorial acceptability was also higher. }\end{array}$ & [41] \\
\hline Resveratrol & Niosomes & $\begin{array}{l}\text { Surfactants sorbitan } \\
\text { monostearate (S60), } \\
\text { labrasol (Lab) and } \\
\text { maisine 35-1(Mai), and } \\
\text { lauryl alcohol (Dod) as } \\
\text { stabilizer }\end{array}$ & $\begin{array}{l}\text { Niosomes were prepared by thin film hydration } \\
\text { method. About } 10 \%(v / v) \text { of niosomes } \\
\text { suspension was added to yogurt. The texture } \\
\text { parameters (firmness and adhesiveness) of } \\
\text { yogurt fortified with Mai-Dod and S60-Dod } \\
\text { niosomes were the same as of control ones. } \\
\text { Yogurt enriched with Lab-Dod niosomes } \\
\text { showed the decrease in the adhesiveness. }\end{array}$ & [42] \\
\hline
\end{tabular}




\subsection{Other Bioactive Components}

Some publications presented research on yogurt fortification with vitamin $D_{3}$, which is fat-soluble and susceptible to the degradation by low $\mathrm{pH}, \mathrm{UV}$, and oxidation [46-48]. Vitamin $\mathrm{D}_{3}$ was delivered in the form of spray-dried nanoliposomes [49], nanocapsules based on the lipid carrier precirol [50], oil-in-water emulsion stabilized by whey protein or by whey protein plus carboxymethylcellulose [51], or encapsulated in re-assembled casein micelles [50]. Encapsulated vitamin $\mathrm{D}_{3}$ showed the high stability against deterioration during the shelf life of yogurt. Moreover, the investigation of bioavailability demonstrated that the delivery of vitamin $\mathrm{D}_{3}$ in the encapsulated form is feasible [51,52]. The addition of vitamin $\mathrm{D}_{3}$ increases the high nutritional value of yogurt, is beneficial for human health, and helps to overcome vitamin deficiency in the diet.

Attempts were made to entrap other micronutrients into yogurt. First, yogurt is considered as a suitable vehicle for iron because the iron-fortified dairy products have high iron bioavailability [53]. The encapsulation of iron is aimed at the elimination of the effect on taste, appearance, product stability, and lipid oxidation [54,55]. Iron as a core material is used in the form of ferrous sulfate, ferric ammonium sulfate, ferrous bisglycinate, and ferrous lactate. Usually, iron is encapsulated in the combination with vitamin $C$, which facilitates nonheme iron absorption and participates in its metabolism [56]. The microcapsules were prepared using vegetable fats or polyglycerol monostearate as a coating material [53,57]. The effect on the sensory properties of microcapsules carrying different iron salts was different. Yogurt fortified with ferrous bisglycinate and ferrous lactate had the lower acceptability in terms of texture, flavor, and appearance, while yogurt fortified with encapsulated ferrous sulfate was not statistically different from a control yogurt [57]. In the presence of iron in polyglycerol monostearate-based microcapsules, the lipid oxidation process was significantly slower as compared to nonencapsulated iron [53]. Recently, for yogurt fortification, iron-entrapped niosomes formed by the selfassembly of non-ionic surfactants in aqueous media were developed by the ethanol injection method [58]. They were found to be suitable for yogurt functionalization since they had no effect on the textural and rheological properties of yogurt. Moreover, addition experiments demonstrated that whey proteins stabilize niosomes.

Recently, a few reports were published studying the encapsulation of plant essential oils and their delivery into yogurt [59-61]. Their addition is beneficial due to their antimicrobial and antioxidant activities [62]. The encapsulation solves the problem of their stability and increases the value of fermented milk products. Yogurt supplemented with the essential oil of basil, mint, fennel, or lavender, which were encapsulated in sodium alginate, had better characteristics in terms of antioxidant activity compared to the control sample. The best effect was achieved by adding the encapsulated basil essential oil. The decrease of antioxidant activity after 20 days of storage was not large [60]. Essential oils are a source of flavoring agents. For the preparation of flavored yogurt, the microcapsules prepared by coating Mellissa oil with sodium caseinate and whey protein isolate were added. The encapsulation prevented the spontaneous release of essential oil, and the supplementation increased the antioxidant activity of products. The addition of microcapsules at the concentration of $0.75-1.5 \%(w / v)$ did not change the sensory properties of yogurt [59]. Garlic essential oil is known for its antibacterial activity against both Gram-positive and Gramnegative bacteria. It is rich in organosulfur compounds responsible for the antimicrobial properties. Allicin, which is very sensitive to high temperature and high $\mathrm{pH}$ values, is the major component of the garlic essential oil. The encapsulation can increase its stability and solubility in water-based foods. Moreover, the encapsulation suppresses the unpleasant and annoying smell of garlic essential oil. For that purpose, nanophytosomes containing the oil were developed, characterized, and used in yogurt. Nanophytosomes were obtained using phosphatidylcholine and fabricated by the thin-layer hydration method and following homogenization or probe sonication, or the combination of homogenization and probe sonication. The nanophytosomes showed stable antioxidant activity during the storage time of 30 days. The addition of nanophytosomes had no effect on the texture and 
color of the prepared yogurt. The difference in aroma between the control sample and the sample supplemented with the nanophytosomes carrying garlic essential oil was low [61].

Yogurt is considered as a particularly suitable food matrix for fortification with longchain omega-3 polyunsaturated fatty acids (PUFA) due to its popularity among consumers and storage conditions at lower temperatures favorable for fatty acids stability. PUFA has health benefits including the prevention of cardiovascular diseases and reduction of inflammation. Moreover, PUFA positively affects cognitive health and age-related decline in muscle mass. In the diet, eicosapentaenoic acid (EPA) and docosahexaenoic acid (DHA), which are found in fish oil, are the most important [63]. To elevate the daily intake of PUFA and mask the undesirable sensory properties of fish oil, various encapsulation forms were developed for the delivery into yogurt. Micro- and double emulsions $[64,65]$, nanoliposomes [66], and particles obtained by the coacervation method using gelatin/acacia gum or by the thermal polymerization of whey proteins were prepared $[67,68]$. The encapsulation protects unsaturated fatty acids from deterioration. The authors emphasize the reduction in peroxide value and the higher content of EPA and DHA compared to yogurt containing free fish oil after three weeks of storage. Overall, the sensory characteristics of yogurt enriched in encapsulated fish oil are acceptable $[64,66,67]$. However, depending on the encapsulation method and the amount of fish oil, an unfavorable fishy taste might be detected [65]. Fish oil can be incorporated into the nanoemulsion together with $\gamma$-oryzanol, which is a mixture of ferulic acid esters of triterpene alcohols and sterols. $\gamma$-Oryzanol is one of the major bioactive compounds in rice bran and has antioxidant and anti-inflammatory activity [69]. In yogurt, $\gamma$-oryzanol protects fish oil against deterioration acting as an antioxidant [70]. In addition to fish oil, algal oil can also serve as a source of DHA and can be a good alternative for vegetarians and vegans. Lane et al. showed that the consumption of yogurt enriched in algal oil nanoemulsions increased the bioavailability of DHA compared to bulk oil [71]. Sweet almond oil and sesame oil are also rich in mono- and polyunsaturated fatty acids. Recently, the investigation of the properties of yogurt enriched in nanoemulsions of those oils has been published. Fortified yogurt exhibited reduced syneresis, lower $\mathrm{pH}$ values, and increased antioxidant activity, since those oils contain various phytochemicals and antioxidants. Sensory analysis showed that yogurt enriched in sesame oil nanoemulsions had the highest score [72]. Screening of scientific papers shows that coencapsulation of bioactive components is a quite a scarce phenomenon. Comunian et al. coencapsulated echium oil rich in polyunsaturated fatty acids, especially stearidonic acid and a mixture of phytosterols and sinapic acid known as an antioxidant. Microcapsules were obtained by the complex coacervation method using gelatin and arabic gum or cashew gum as wall materials. The encapsulation provided the stability of bioactive components and their release in gastric and intestinal fluids. The fortification of yogurt with microcapsules did not change its physicochemical, rheological, and sensorial properties [73].

In addition, to functionalize yogurt, encapsulation systems for purple rice bran oil rich in $\alpha$-tocopherol, $\gamma$-tocotrienol, and $\gamma$-oryzanol were developed based on nanoemulsions [74], and for Nigella sativa oil containing thymoquinone [75]. The latter was emulsified and spray-dried using modified starch and maltodextrin as wall materials. The encapsulation of a palm tocotrienol rich fraction in the form of alginate-chitosan microcapsules increased the stability of tocotrienols, especially when the microcapsules were incorporated into yogurt [76]. The extract of mushroom Agaricus bisporus, which is largely used over the world, contains bioactive compounds such as ergosterol and mycosterol, exhibiting beneficial properties for human health. The extract was encapsulated by spray drying using maltodextrin crosslinked with citric acid as a carrier material and was found to be a promising bioactive ingredient for yogurt functionalization [77]. For the dairy products fortification with microalgae, Spirulina-loaded alginate microcapsules coated with whey protein concentrate were prepared. Microencapsulation improved the acceptance of fortified yogurt, making the color of the final product lighter [78]. 


\subsection{Probiotic Microorganisms}

Streptococcus thermophilus and Lactobacillus delbrueckii subsp. bulgaricus as starter cultures of yogurts are considered to have health benefits. However, they are not natural inhabitants of the intestine. To increase yogurt functionality, it can be supplemented with probiotic microorganisms. The genera of Lactobacillus and Bifidobacterium are the most studied microorganisms for functional food production. However, most of them show the low tolerance to acidic and aerated media. Moreover, the number of probiotic microorganisms decreases due to the action of gastric juice and bile salts [79]. To exhibit therapeutic benefits, products have to contain at least $10^{6}$ live microorganisms per $\mathrm{g}$ or $\mathrm{mL}$ of the product [80]. To increase the viability of probiotic microorganisms, the encapsulation approach has been considered as a way to solve this problem. The encapsulation of bifidobacteria by emulsification using whey proteins as a wall material and following spray drying increased viable counts of bacteria during the storage of yogurt at $4{ }^{\circ} \mathrm{C}$. However, this technique of encapsulation was destructive for microorganisms due to the high temperature of the process [81]. Bifidobacteria microencapsulated in $\mathrm{k}$-carrageenan were also protected from the low $\mathrm{pH}$ of yogurt, and there was no decline of cell number in samples stored for 30 days in the refrigerator. However, consumers preferred yogurt without encapsulated bacteria due to the grainy texture of the fortified one [82,83]. Pinto et al. used gum arabic, inulin, and maltodextrin as wall materials for the encapsulation of Bifidobacterium lactis by spray drying. The addition of encapsulated B. lactis to yogurt improved its firmness and adhesiveness. However, the encapsulation did not provide additional protection for B. lactis [84]. A similar effect was observed for bifidobacteria microcapsules prepared by spray drying using sweet whey or inulin plus sweet whey for encapsulation [85].

The encapsulation of Lactobacillus paracasei by the gelation technique using sodium caseinate-gellan gum was found to be a suitable manner for the delivery of bacteria because encapsulated samples showed a higher survival rate than nonencapsulated bacteria. Moreover, the addition of microcapsules and milk protein concentrate improved syneresis and viscosity during the storage of yogurt samples [86]. The microcapsules of the Lactobacillus acidophilus strain were prepared by the complex coacervation method using pectin and casein as wall materials [87] and combining ionic gelation and coacervation methods when pectin and whey protein concentrate served as the wall and coating material, respectively [88]. In both cases, the fortification of yogurt with the encapsulated probiotics resulted in the lower values of post-acidification and the higher viability of Lactobacillus acidophilus during the cold storage. The microcapsules obtained by the combined method affected negatively the texture of yogurt. It was less acceptable compared to the one with free microorganisms [88]. Despite that, probiotics embedded into alginate beads or chitosan-coated alginate beads were one of the most popular and well-known delivery systems for yogurt $[89,90]$. Those simple microgels do not ensure the viability of microorganisms exposed to gastric fluids [91]. To increase the protection of bacteria under gastrointestinal conditions, a new approach was developed to produce synbiotic microcapsules. Together with bacteria, prebiotics such as galactooligosaccharides or lactitol were encapsulated in chitosan-coated alginate beads [92]. Although the survival of bacteria enhanced, the quality of yogurt in terms of texture parameters reduced. For yogurt fortification with Lactobacillus rhamnosus, protein-based microcapsules were developed using soy protein isolate crosslinked by transglutaminase [93]. The system was found as a suitable alternative to polysaccharide gelation technology. Aljouni et al. showed that whey protein-encapsulated probiotics exhibited increased bioaccessibility in the colon [94].

\section{Kefir Fortification with Nano/Microencapsulated Bioactive Ingredients}

Kefir is one of the oldest fermented milk beverages. It is believed to have originated from the Caucasus region before 2000 BC. Nowadays, kefir is a popular fermented product in Eastern Europe. It is produced by inoculating milk with kefir grains containing a complex 
mixture of bacteria and yeasts. The flavor and aroma of kefir is the result of metabolic activity and the relationship of a number of bacteria and yeasts species [95].

Kefir is a probiotic drink having human health beneficial effects [96]. However, there are a few publications on the additional functionalization of kefir by the incorporation of encapsulated bioactive components. Yüksel-Bilsel and Sahin-Yesilcubuk developed the functional kefir fortified with encapsulated structured lipids [97]. Microcapsules were prepared by the method of coacervation using gelatin and gum arabic as wall materials. The enzyme, transglutaminase, was used as a crosslinking agent. Fortified kefir was stored within a period of 10 days at $4{ }^{\circ} \mathrm{C}$ and remained acceptable in terms of $\mathrm{pH}$ value, acidity, and color. Moreover, kefir exhibited no inhibitory effect on oil release in an in vitro digestion study.

Despite the probiotic nature of kefir itself [98], it can be additionally supplemented with probiotics to ensure the sufficient daily consumption of microorganisms. Usually, the encapsulation increases the viability of probiotics during the refrigerated storage and under acid conditions in the digestive tract. That was exemplified by the encapsulation of Bifidobacterium animalis ssp. lactis BB12 in alginate beads [99] and the preparation of electrospun alginate fibers carrying Lactobacillus paracasei KS-199 [100].

The consumption of kefir is growing all over the world. Kefir grains are found all over Europe and beyond. However, nowadays, the popularity of kefir is on the level as the status of yogurts in the 1970s [98]. This fact could explain the limited number of scientific papers on the fortification of kefir by nano/microencapsulated bioactive ingredients. On the other hand, there are a lot of studies concerning health benefits of kefir and its other uses such as the exploitation of kefiran, extracellular polysaccharide produced by LAB [98].

\section{Cheese Fortification with Nano/Microencapsulated Bioactive Ingredients}

\subsection{Probiotic Microorganisms}

For cheese fortification with probiotics, the main challenge is related to the maintenance of probiotic viability during cheese processing and storage. Moreover, the traditional sensory properties of cheese have to be not changed. The survival of bacteria under gastric conditions followed by the colonization of the colon is also very important. Although various factors such as low $\mathrm{pH}$, the presence of salt, oxygen, and the long storage time affect the viability of probiotics, cheese is considered to be a better vehicle for probiotics than yoghurt. It has the higher content of fat and proteins; its dense matrix and good buffering capacity provide greater protection to probiotics [101]. Nevertheless, the survival improvement remains an actual question. Table 3 summarizes the recent research efforts in this direction [102-113]. As seen, various types of cheese, soft and hard, are fortified with encapsulated bacteria from the Lactobacillus and Bifidobacterium genera. Two methods, i.e., extrusion and emulsification, remain the most popular using alginate as a wall material $[104,107,108,112]$. In addition, the gelation method based on the enzyme action $[105,111]$ or Maillard reaction [103] is used for the fabrication of probiotic carrier.

Usually, the authors observe the survival improvement for the encapsulated probiotics compared to free cells. However, it is quite difficult to estimate the effectiveness of various encapsulation systems and compare them with each other. The investigations are performed using different bacteria strains and different cheese types. The period of time for cheese storage and for the survival evaluation of microorganisms is also different. 
Table 3. Encapsulation of probiotics for cheese fortification.

\begin{tabular}{|c|c|c|c|c|c|}
\hline Cheese Type & Microorganism & $\begin{array}{l}\text { Encapsulation } \\
\text { Techniques } \\
\text { and Systems }\end{array}$ & $\begin{array}{l}\text { Encapsulant } \\
\text { Materials }\end{array}$ & Observations & References \\
\hline Cream cheese & $\begin{array}{l}\text { Lactobacillus } \\
\text { rhamnosus }\end{array}$ & $\begin{array}{l}\text { Microgel } \\
\text { particles } \\
\text { obtained by } \\
\text { aerosol } \\
\text { spraying }\end{array}$ & $\begin{array}{l}\text { Sodium } \\
\text { alginate }\end{array}$ & $\begin{array}{l}\text { L. rhamnosus remained viable (min } 10^{6} \\
\mathrm{CFU} / \mathrm{g} \text { ) over } 35 \text { days of storage at } 4^{\circ} \mathrm{C} \text {. The } \\
\text { addition of encapsulated probiotic bacteria } \\
\text { resulted in a firmer and thicker cheese. }\end{array}$ & [102] \\
\hline $\begin{array}{l}\text { White brined } \\
\text { cheese }\end{array}$ & $\begin{array}{l}\text { Lactobacillus } \\
\text { rhamnosus }\end{array}$ & $\begin{array}{l}\text { Microcapsules } \\
\text { obtained by } \\
\text { cold gelation }\end{array}$ & $\begin{array}{l}\text { Maillard } \\
\text { reaction } \\
\text { products of iso- } \\
\text { maltooligosac- } \\
\text { charides and } \\
\text { whey proteins }\end{array}$ & $\begin{array}{l}\text { Droplet-like capsules with a smooth surface, } \\
\text { whose diameter was approximately } 183 \mu \mathrm{m} \text {. } \\
\text { The viability of encapsulated probiotic was } \\
\text { increased compared to free cells during } 90 \\
\text { days of storage at } 4^{\circ} \mathrm{C} \text {. Sensory properties of } \\
\text { cheese were not affected by the addition of } \\
\text { encapsulated bacteria. }\end{array}$ & [103] \\
\hline $\begin{array}{l}\text { White brined } \\
\text { cheese }\end{array}$ & $\begin{array}{l}\text { Bifidobacterium } \\
\text { bifidum, } \\
\text { Lactobacillus } \\
\text { acidophilus }\end{array}$ & $\begin{array}{l}\text { Extrusion, } \\
\text { emulsion }\end{array}$ & $\begin{array}{l}\text { Sodium } \\
\text { alginate for } \\
\text { extrusion and } \\
\text { corn oil and } \\
\text { K-carragenan } \\
\text { for emulsion }\end{array}$ & $\begin{array}{l}\text { Both techniques were effective in keeping } \\
\text { cell counts higher than the therapeutic } \\
\text { minimum during } 90 \text { days of storage at } 4{ }^{\circ} \mathrm{C} \text {. } \\
\text { The content of free fatty acids, acetaldehyde, } \\
\text { and diacetyl was higher as compared to } \\
\text { control sample. }\end{array}$ & [104] \\
\hline $\begin{array}{c}\text { Iranian UF Feta } \\
\text { cheese }\end{array}$ & $\begin{array}{c}\text { Lactobacillus } \\
\text { paracasei }\end{array}$ & $\begin{array}{l}\text { Enzyme } \\
\text { based } \\
\text { gelation } \\
\text { (rennet or } \\
\text { transglutami- } \\
\text { nase) }\end{array}$ & $\begin{array}{l}\text { Sodium } \\
\text { caseinate or } \\
\text { skim milk } \\
\text { powder }\end{array}$ & $\begin{array}{c}\text { The cells entrapped into microcapsules by } \\
\text { rennet-based gelation exhibited the higher } \\
\text { viability compared to } \\
\text { transglutaminase-based gelation. }\end{array}$ & [105] \\
\hline $\begin{array}{c}\text { Iranian UF } \\
\text { white cheese }\end{array}$ & $\begin{array}{l}\text { Lactobacillus } \\
\text { plantarum }\end{array}$ & $\begin{array}{l}\text { Complex } \\
\text { coacervation } \\
\text { followed by } \\
\text { spray drying } \\
\text { or freeze } \\
\text { drying }\end{array}$ & $\begin{array}{l}\text { Whey protein } \\
\text { isolate and } \\
\text { gum arabic }\end{array}$ & $\begin{array}{l}\text { Phytosterol was coencapsulated with } \\
\text { bacteria. Its coencapsulation increased the } \\
\text { viability of bacteria in cheese during } 91 \text { days } \\
\text { of storage at } 4{ }^{\circ} \mathrm{C} \text { in comparison with } \\
\text { encapsulated bacteria alone or free cells. }\end{array}$ & [106] \\
\hline $\begin{array}{l}\text { Iranian white } \\
\text { brined cheese }\end{array}$ & $\begin{array}{l}\text { Lactobacillus } \\
\text { acidophilus }\end{array}$ & Extrusion & $\begin{array}{l}\text { Calcium } \\
\text { alginate and } \\
\text { resistant starch }\end{array}$ & $\begin{array}{c}\text { The survival of bacteria was increased in } \\
\text { cheese and was equal to } \geq 10^{7} \mathrm{CFU} / \mathrm{g} \text { after } 6 \\
\text { months of storage. }\end{array}$ & [107] \\
\hline $\begin{array}{c}\text { Iranian UF } \\
\text { white cheese }\end{array}$ & $\begin{array}{l}\text { Lactobacillus } \\
\text { plantarum, } \\
\text { Bifidobacterium } \\
\text { bifidum, } \\
\text { Lactobacillus } \\
\text { casei subsp. } \\
\text { casei }\end{array}$ & Extrusion & $\begin{array}{l}\text { Sodium } \\
\text { alginate }\end{array}$ & $\begin{array}{c}\text { After } 60 \text { days of cheese storage at } 8-10{ }^{\circ} \mathrm{C} \text {, } \\
\text { the counts of each encapsulated bacterium } \\
\text { were higher than the therapeutic minimum } \\
\qquad\left(10^{6}-10^{7} \mathrm{CFU} / \mathrm{g}\right) .\end{array}$ & [108] \\
\hline $\begin{array}{l}\text { Cheddar } \\
\text { cheese }\end{array}$ & $\begin{array}{l}\text { Bifidobacterium } \\
\text { bifidum }\end{array}$ & $\begin{array}{l}\text { Emulsification/ } \\
\text { gelation }\end{array}$ & $\begin{array}{l}\text { K-carrageenan } \\
\text { internal odium } \\
\text { or sodium } \\
\text { alginate }\end{array}$ & $\begin{array}{l}\text { For encapsulated bacteria, the decrease of } \\
\text { viability was slower over a period of } 35 \text { days. } \\
\text { The encapsulant sodium alginate showed the } \\
\text { better results than } \kappa \text {-carrageenan under } \\
\text { simulated gastrointestinal conditions. }\end{array}$ & [109] \\
\hline $\begin{array}{l}\text { Cheddar } \\
\text { cheese }\end{array}$ & $\begin{array}{l}\text { Bifidobacterium } \\
\text { longum }\end{array}$ & $\begin{array}{l}\text { Co-axial } \\
\text { droplet } \\
\text { extrusion, } \\
\text { emulsifica- } \\
\text { tion/internal } \\
\text { gelation }\end{array}$ & $\begin{array}{l}\text { Sodium } \\
\text { alginate or } \\
\text { palmitoylated } \\
\text { alginate }\end{array}$ & $\begin{array}{l}\text { After } 21 \text { days of cheese storage at } 4{ }^{\circ} \mathrm{C} \text {, } \\
\text { bacteria encapsulated by } \\
\text { emulsification/internal gelation showed } 2 \\
\log \mathrm{CFU} / \mathrm{mL} \text { reduction as compared to free } \\
\text { cells with } 4 \log \mathrm{CFU} / \mathrm{mL} \text { reduction. }\end{array}$ & [110] \\
\hline
\end{tabular}


Table 3. Cont.

\begin{tabular}{|c|c|c|c|c|c|}
\hline $\begin{array}{l}\text { Cheese } \\
\text { Type }\end{array}$ & Microorganism & $\begin{array}{l}\text { Encapsulation } \\
\text { Techniques and } \\
\text { Systems }\end{array}$ & $\begin{array}{l}\text { Encapsulant } \\
\text { Materials }\end{array}$ & Observations & References \\
\hline $\begin{array}{l}\text { Kariesh } \\
\text { cheese }\end{array}$ & $\begin{array}{l}\text { Bifidobacterium } \\
\text { adolescentis }\end{array}$ & $\begin{array}{l}\text { Rennet based } \\
\text { gelation }\end{array}$ & Milk proteins & $\begin{array}{l}\text { The viability of encapsulated bacteria } \\
\text { increased during two weeks of cheese } \\
\text { cold storage. }\end{array}$ & [111] \\
\hline $\begin{array}{l}\text { Mozzarella } \\
\text { cheese }\end{array}$ & $\begin{array}{l}\text { Lactobacillus } \\
\text { paracasei }\end{array}$ & $\begin{array}{l}\text { Emulsification/internal } \\
\text { gelation }\end{array}$ & Sodium alginate & $\begin{array}{l}\text { Encapsulation provided no protection } \\
\text { against simulated gastric juice. }\end{array}$ & [112] \\
\hline $\begin{array}{l}\text { Soft goat } \\
\text { cheese }\end{array}$ & $\begin{array}{l}\text { Lactobacillus } \\
\text { plantarum }\end{array}$ & Spray drying & Skim milk & $\begin{array}{l}\text { After } 8 \text { weeks of cheese storage, the } \\
\text { high level of } 8.82 \log \text { CFU/g was } \\
\text { found for the encapsulated bacteria, } \\
\text { while the free-cell number decreased } \\
\text { to } 6.9 \text { log CFU/g. The addition of } \\
\text { spray-dried bacteria did not change } \\
\text { the properties of cheese (pH value, } \\
\text { chemical composition, sensory } \\
\text { quality). }\end{array}$ & [113] \\
\hline
\end{tabular}

\subsection{Phenolic Compounds (Phenolics) Containing Components}

Cheese is a good candidate for the development of functional food. There is a lot of different cheese taste, its shelf life is long, and cheese is a very popular milk product. Having in mind the production on an industrial scale, cheese is fortified mainly by the extracts of plants, but not by pure compounds in order not to increase the production cost. The fortification of cheese with free phenolics can influence the cheese texture, color, and taste during its storage. Moreover, phenolics interact with milk components and lose their antioxidant properties [114]. The extracts of rosemary, fennel, and chamomile were encapsulated by the atomization/coagulation technique using sodium alginate as a coating material. $[115,116]$. The incorporation of the prepared microcapsules into cottage cheese did not change its nutritional and color parameters. Moreover, the antioxidant activity was maintained more efficiently under cheese storage compared to the free form of extracts. The inexpensive liposomal technology using soy lecithin was developed for the green tea catechins delivery into low-fat and full-fat hard cheese $[117,118]$. The encapsulation improved the recovery of catechins from digesta in an in vitro gastrointestinal digestion system. However, the recovery of liposomal catechins was significantly dependent on their chemical structure $[118,119]$. The application of liposomal technology might significantly increase the antioxidant potential of cheese and, overall, the human diet. For the olive phenolics encapsulation and their delivery into white soft cheese, the microcapsules were prepared by ultrasonication and following spray drying. Skim milk proteins and maltodextrin were used as wall materials. The encapsulation ensured invariable antioxidant activity of cheese during 30 days of storage [120]. Pereira et al. showed that quercetin-cyclodextrin inclusion complexes are a suitable approach for fresh cheese fortification with one of the most active flavonoids, which is very sensible to oxidants and light. [121]. $\gamma$-Cyclodextrin was found to be the better host molecule than $\beta$-cyclodextrin due to the larger interior cavity and deeper guest inclusion. At the concentration of $0.03-0.04 \%(w / w)$, quercetincyclodextrin inclusion complexes resulted in the minor organoleptic changes such as the firmer texture and yellowish color.

Taken together, the scientific publications on the fortification of cheese with nano/microencapsulated phenolics are not numerous.

\subsection{Other Bioactive Components}

For cheese, carotenoids serve as health beneficial compounds or colorants [14,122]. Recently, the investigation on the supplementation of Appezeller cheese and Queso Blanco cheese with microencapsulated tomato extract as a source of lycopene has been performed. 
For the fabrication of microcapsules, the emulsion was spray-dried using maltodextrin as a coating material. Sensory properties of cheese were improved due to tomato taste and higher yellowness $[123,124]$. The pepper extract rich in carotenoids and polyphenols was encapsulated in alginate beads by the ionic gelation method and used for the production of a new Labneh cheese [125]. For the production of Cheddar and Gouda cheeses, the colorant annatto responsible for the yellowish-red color is used. Annatto is extracted from the seeds of the Bixa orellana plant and is composed of the two major carotenoids, norbixin and bixin [122]. However, during the manufacturing process, the small amount of annatto $(5-10 \%)$ is transferred to a whey stream and reduces the quality of whey powder. Moreover, there are regulatory restrictions concerning the amount of annatto in whey, especially for the application in infant formula [126]. To reduce the amount of colorant in whey powder, a new alternative based on the encapsulation of annatto was proposed. The colorant was complexed with chitosan [127,128] or entrapped into casein-chitosan complexes [129]. Moreover, enzyme-responsive microcapsules that can selectively color the cheese matrix were developed [130].

There are a few works aimed at the delivery of omega- 3 originated from animal and vegetables sources to cheese. Chia seed oil is rich in $\alpha$-linolenic acid. Sheep's milk cheese was fortified with chia oil emulsion stabilized by calcium caseinate. The enrichment did not affect the cheese-making process and microbial quality during the ripening period [131]. Double emulsions of canola oil rich in omega- 3 were prepared by ultrasonication and displaced in Cheddar cheese [132]. Cod liver oil emulsions stabilized by self-assembly structures based on saturated monoglycerides ensured the good retention of omega-3 source in the cheese curd. The texture parameters were similar to unfortified fresh soft cheese [133]. Stratulat et al. prepared the flaxseed oil emulsion stabilized by calcium caseinate. That emulsion was not only rich in $\alpha$-linolenic acid but also served as a carrier of vitamin $\mathrm{D}_{3}$ for the delivery into cheese [134]. In addition, vitamin $\mathrm{D}_{3}$ can be delivered in the form of liposomes [135]. Flaxseed oil-based emulsion can also be used for the encapsulation of coenzyme $Q_{10}$ or coencapsulation with vitamin $E$ and $A[136,137]$. As a result, the retention of the lipophilic compounds in the curd increased, and their stability and functionality were also improved during cheese storage.

For hydrophilic vitamin $\mathrm{B}_{12}$, double emulsion (water-in-oil-in-water) was developed using butter oil, lipophilic emulsifier polyglycerol polyricinoleate, and hydrophilic emulsifier sodium caseinate [138]. The encapsulation improved the retention of vitamin $B_{12}$ in the cheese curd as compared to the nonencapsulated vitamin and increased its stability during in vitro gastric digestion. Cheese could be a suitable vehicle for iron supplementation due to its popularity and large consumption. However, the fortification of cheese with microencapsulated ferrous sulfate negatively affects its organoleptic properties, and the microencapsulation is unable to mask the iron taste, color, and odor [139].

Bioactive compounds are incorporated into cheese to increase its health benefits. However, some of them can serve as a natural preservative. This is very important for soft, fresh cheese having the high level of moisture. Lemongrass essential oil composed mainly of $\alpha$-citral and $\beta$-citral was encapsulated into microparticles by the preparation of emulsion and the following spray drying using Arabic gum and maltodextrin as wall materials. The obtained microcapsules were effective in controlling the proliferation of microorganisms in Coalho cheese during 21 days of storage [140]. The encapsulated rosemary essential oil at the concentration of $0.5 \%$ delayed microorganism growth in Minas frescal cheese. Microcapsules were prepared by spray drying using inulin and whey protein isolate as wall materials [141].

\section{Conclusions}

Intensive research is underway for increasing the functionality of popular fermented milk products. Despite the health benefits of fermented milk products themselves, research is stimulated by the growing consumer interest in healthy foods. Kefir, yogurt, and cheese are appropriate vehicles for various bioactive ingredients such as carotenoids, 
phenolic compounds, probiotics, omega-3, and other micronutrients. The encapsulation serves for the enhancement of stability and solubility of bioactive compounds or the survival improvement of probiotic microorganisms during product processing, storage, or undergoing gastric digestion. The analysis of scientific papers shows that with some exceptions, the delivery system is proposed for each core material separately. Further research could be aimed for the development of more complex delivery systems allowing the fortification of fermented milk products at once with several different additives. In some cases, the coencapsulation can be complicated due to the different and not always compatible physicochemical properties of bioactive ingredients.

Author Contributions: Writing-original draft preparation, R.G.; A.B.; writing-review and editing, J.S.; supervision, J.S. All authors have read and agreed to the published version of the manuscript.

Funding: This research received no external funding.

Institutional Review Board Statement: Not applicable.

Informed Consent Statement: Not applicable.

Data Availability Statement: The data presented in this study are available on request from the corresponding author.

Conflicts of Interest: The authors declare no conflict of interest.

Sample Availability: Samples of the compounds are not available from the authors.

\section{References}

1. Teneva-Angelova, T.; Balabanova, T.; Boyanova, P.; Beshkova, D. Traditional Balkan fermented milk products. Eng. Life Sci. 2018, 18, 807-819. [CrossRef]

2. Shiby, V.K.; Mishra, H.N. Fermented milks and milk products as functional foods-A review. Crit. Rev. Food Sci. Nutr. 2013, 53, 482-496. [CrossRef]

3. Garcia-Burgos, M.; Moreno-Fernandez, J.; Alferez, M.J.M.; Diaz-Castro, J.; Lopez-Aliaga, I. New perspectives in fermented dairy products and their health relevance. J. Funct. Foods 2020, 72, 104059. [CrossRef]

4. Companys, J.; Pedret, A.; Valls, R.M.; Sola, R.; Pascual, V. Fermented dairy foods rich in probiotics and cardiometabolic risk factors: A narrative review from prospective cohort studies. Crit. Rev. Food Sci. Nutr. 2020. [CrossRef]

5. Farag, M.A.; Jomaa, S.A.; El-Wahed, A.A.; El-Seedi, H.R. The many faces of kefir fermented dairy products: Quality characteristics, flavour chemistry, nutritional value, health benefits and safety. Nutrients 2020, 12, 346. [CrossRef]

6. Dias, D.R.; Botrel, D.A.; de Barros Fernandes, R.V.; Borges, S.V. Encapsulation as a tool for bioprocessing of functional foods. Curr. Opin. Food Sci. 2017, 13, 31-37. [CrossRef]

7. Nedovic, V.; Kalusevic, A.; Manojlovic, V.; Levie, S.; Bugarski, B. An overview of encapsulation technologies for food applications. Procedia Food Sci. 2011, 1, 1806-1815. [CrossRef]

8. Vidallon, M.L.P.; Teo, B.M. Recent developments in biomolecule-based nanoencapsulation systems for antimicrobial delivery and biofilm disruption. Chem. Commun. 2020, 56, 13907-13917. [CrossRef]

9. Soukoulis, C.; Bohn, T. A comprehensive overview on the micro- and nano-technological encapsulation advances for enhancing the chemical stability and bioavailability of carotenoids. Crit. Rev. Food Nutr. 2018, 58, 1-36. [CrossRef]

10. Shishir, M.R.I.; Xie, L.; Sun, C.; Zheng, X. Advances in micro and nano-encapsulation of bioactive compounds using biopolymer and lipid-based transporters. Trends Food Sci. Technol. 2018, 78, 34-60. [CrossRef]

11. Khar, A.R.; Vasisht, N. Nanoendapsulation in the food industry: Technology of the future. In Microencapsulation in the Food Industry: A Practical Implementation Guide; Gaonkar, A.G., Vasisht, N., Khare, A.R., Sobel, R., Eds.; Elsevier: Amsterdam, The Netherlands, 2014; pp. 151-155.

12. McClements, D.J. Recent developments in encapsulation and release of functional food ingredients: Delivery by design. Curr. Opin. Food Sci. 2018, 23, 80-84. [CrossRef]

13. McClements, D.J. Delivery by design (DbD): A standardized approach to the development of efficacious nanoparticle- and microparticle-based delivery systems. Compr. Rev. Food Sci. Food Saf. 2018, 17, 200-219. [CrossRef]

14. Rodriguez-Concepcion, M.; Avalos, J.; Bonet, L.; Boronat, A.; Gomez-Gomez, L.; Hornero-Mendez, D.; Limon, M.C.; MelendezMartinez, A.J.; Olmedilla-Alonso, B.; Palou, A.; et al. A global perspective on carotenoids: Metabolism, biotechnology, and benefits for nutrition and health. Prog. Lipid Res. 2018, 70, 62-93. [CrossRef]

15. Melendez-Martinez, A.J. An overview of carotenoids, apocarotenoids, and vitamin A in agro-food, nutrition, health, and disease. Mol. Nutr. Food Res. 2019, 63, 1801045. [CrossRef]

16. Meléndez-Martínez, A.J.; Böhm, V.; Borge, G.I.A.; Cano, M.P.; Fikselová, M.; Gruskiene, R.; Lavelli, V.; Loizzo, M.R.; Mandić, A.I.; Brahm, P.M.; et al. Carotenoids: Considerations for Their Use in Functional Foods, Nutraceuticals, Nutricosmetics, Supplements, 
Botanicals, and Novel Foods in the Context of Sustainability, Circular Economy, and Climate Change. Annu. Rev. Food Sci. Technol. 2021, 12, 433-460. [CrossRef]

17. Sandmann, G. Antioxidant protection from UV- and light-stress related to carotenoid structures. Antioxidants 2019, 8, 219. [CrossRef]

18. Horuz, T.I. Encapsulation of tomato peel extract into nanofibers and its application in model food. J. Food Process. Preserv. 2019, 43, e14090.

19. Šeregelj, V.; Šaponjac, V.T.; Lević, S.; Kalušević, A.; Ćetković, G.; Čanadanović-Brunet, J.; Nedović, V.; Stajčić, S.; Vulić, J.; Vidaković, A. Application of encapsulated natural bioactive compounds from red pepper waste in yogurt. J. Microencapsul. 2019, 36, 704-714. [CrossRef] [PubMed]

20. Gomes, L.M.M.; Petito, N.; Costa, V.G.; Falcao, D.Q.; de Lima Araujo, K.G. Inclusion complexes of red bell pepper pigments with $\beta$-cyclodextrin: Preparation, characterization and application as natural colorant in yogurt. Food Chem. 2014, 148, 428-436. [CrossRef]

21. De Oliveira Cavalcanti Medeiros, A.K.; de Carvalho Gomes, C.; de Araujo Amaral, M.L.Q.; de Medeiros, L.D.G.; Medeiros, I.; Porto, D.L.; Aragao, C.F.S.; Maciel, B.L.L.; de Araujo Morais, A.H.; Passos, T.S. Nanoencapsulation improved water solubility and color stability of carotenoids extracted from Cantaloupe melon (Cucumis melo L.). Food Chem. 2019, 270, 562-572. [CrossRef]

22. Coronel-Aquilera, C.P.; Martin-Gonzalez, M.F.S. Encapsulation of spray dried $\beta$-carotene emulsion by fluiized bed coating technology. LWT Food Sci. Technol. 2015, 62, 187-193. [CrossRef]

23. Toniazzo, T.; Berbel, I.F.; Cho, S.; Favaro-Trindade, C.S.; Moraes, I.C.F.; Pinho, S.C. $\beta$-Carotene-loaded liposome dispersions stabilized with xanthan and guar gums: Physico-chemical stability and feasibility of application in yogurt. LWT Food Sci. Technol. 2014, 59, 1265-1273. [CrossRef]

24. Molina, C.V.; Lima, J.G.; Moraes, I.C.F.; Pinho, S.C. Physicochemical characterization and sensory evaluation of yogurts incorporated with beta-carotene-loaded solid lipid microparticles stabilized with hydrolyzed soy protein isolate. Food Sci. Biotechnol. 2019, 28, 59-66. [CrossRef]

25. Donhowe, E.G.; Flores, F.P.; Kerr, W.L.; Wicker, L.; Kong, F. Characterization and in vitro bioavailability of $\beta$-carotene: Effects of microencapsulation method and food matrix. LWT Food Sci. Technol. 2014, 57, 42-48. [CrossRef]

26. De Campo, C.; Assis, R.Q.; da Silva, M.M.; Costa, T.M.H.; Paese, K.; Guterres, S.S.; de Oliveira Rios, A. Incorporation of zeaxanthin nanoparticles in yogurt: Influence on physicochemical properties, carotenoid stability and sensory analysis. Food Chem. 2019, 301, 125230. [CrossRef]

27. Taksima, T.; Limpawattana, M.; Klaypradit, W. Astaxanthin encapsulated in beads using ultrasonic atomizer and application in yogurt as evaluated by consumer sensory profile. LWT Food Sci. Technol. 2015, 62, 431-437. [CrossRef]

28. Gomez-Estaca, J.; Comunian, T.A.; Montero, P.; Ferro-Furtado, R.; Favaro-Trindade, C.S. Encapsulation of an astaxanthincontaining lipid extract from shrimp waste by complex coacervation using a novel-gelatin-cashew gum complex. Food Hydrocoll. 2016, 61, 155-162. [CrossRef]

29. Rutz, J.K.; Borges, C.D.; Zambiazi, R.C.; da Rosa, C.G.; da Silva, M.M. Elaboration of microparticles of carotenoids from natural and synthetic sources for applications in food. Food Chem. 2016, 202, 324-333. [CrossRef]

30. Rutz, J.K.; Borges, C.D.; Zambiazi, R.C.; Crizel-Cardozo, M.M.; Kuck, L.S.; Norena, C.P.Z. Microencapsulation of palm oil by complex coacervation for application in food systems. Food Chem. 2017, 220, 59-66. [CrossRef]

31. Esfanjani, A.F.; Assadpour, E.; Jafari, S.M. Improving the bioavailability of phenolic compounds by loading them within lipid-basewd nanocarriers. Trends Food Sci. Technol. 2018, 76, 56-66. [CrossRef]

32. De Araujo, F.F.; de Paulo Farias, D.; Neri-Numa, I.A.; Pastore, G.M. Polyphenols and their applications: An approach in food chemistry and innovation potential. Food Chem. 2021, 338, 127535. [CrossRef]

33. Shahidi, F.; Ambigaipalan, P. Phenolics and polyphenolics in foods, beverages and spices: Antioxidant activity and health effects-A review. J. Funct. Foods 2015, 8, 820-897. [CrossRef]

34. Yadav, K.; Bajaj, R.K.; Mandal, S.; Saha, P.; Mann, B. Evaluation of total phenol content and antioxidant properties of encapsulated grape seed extract in yoghurt. Int. J. Dairy Technol. 2018, 71, 96-104. [CrossRef]

35. Akgun, D.; Gultekin-Ozguven, M.; Yucetepe, A.; Altin, G.; Gibis, M.; Weiss, J.; Ozcelik, B. Stirred-type yoghurt incorporated with sour cherry extract in chitosan-coated liposomes. Food Hydrocoll. 2020, 101, 105532. [CrossRef]

36. El-Said, M.M.; El-Messery, T.M.; El-Din, H.M.F. The encapsulation of powdered doum extract in liposomes and its application in yoghurt. Acta Sci. Pol. Technol. Aliment. 2018, 17, 235-245.

37. Altin, G.; Gultekin-Ozguven, M.; Ozcelik, B. Liposomal dispersion and powder systems for delivery of cocoa hull waste phenolics via Ayran (drinking yoghurt): Comparative studies on in-vitro bioaccessibility and antioxidant capacity. Food Hydrocoll. 2018, 81, 364-370. [CrossRef]

38. De Figueiredo Paes Barretto, F.J.; Clemente, H.A.; Santana, A.L.B.D.; da Silva Vasconcelo, M.A. Stability of encapsulated and non-encapsulated anthocyanin in yogurt produced with natural dye obtained from Solanum melongena L. bark. Rev. Bras. de Frutic. 2020, 42, e137.

39. El-Messery, T.M.; El-Said, M.M.; Shahein, N.M.; El-Din, H.M.F.; Farrag, A. Functional yoghurt supplemented with orange peel encapsulated using coacervation technique. Pak. J. Biol. Sci. 2019, 22, 231-238. [CrossRef]

40. De Moura, S.C.S.R.; Schettini, G.N.; Garcia, A.O.; Gallina, D.A.; Alvim, I.D.; Hubinger, M.D. Stability of hibiscus extract encapsulated by ionic gelation incorporated in yogurt. Food Bioprocess Technol. 2019, 12, 1500-1515. [CrossRef] 
41. El-Kholy, W.M.; Soliman, T.N.; Muhammad, G.D. Evaluation of date palm pollen (Phoenix dactylifera L.) encapsulation, impact on the nutritional and functional properties of fortified yoghurt. PLoS ONE 2019, 14, e0222789. [CrossRef]

42. Pando, D.; Beltran, M.; Gerone, I.; Matos, M.; Pazos, C. Resveratol entrapped noisome as yoghurt additive. Food Chem. 2015, 170, 281-287. [CrossRef] [PubMed]

43. Rajera, R.; Nagpal, K.; Singh, S.K.; Mishra, D.N. Niosomes: A Controlled and novel drug delivery system. Biol. Pharm. Bull. 2011, 34, 945-953. [CrossRef]

44. Tavakoli, H.; Hosseini, O.; Jafari, S.M.; Katouzian, I. Evaluation of physicochemical and antioxidant properties of yogurt enriched by olive leaf phenolics within nanoliposomes. J. Agric. Food Chem. 2018, 66, 9231-9240. [CrossRef] [PubMed]

45. Sun, Y.; Zhou, W.; Huang, Y. Encapsulation of tartary buckwheat flavonoids and application to yoghurt. J. Microencapsul. 2020. [CrossRef]

46. Markman, G.; Livney, Y.D. Maillard-conjugate based core-shell co-assemblies for nanoencapsulation of hydrophobic nutraceuticals in clear beverages. Food Funct. 2012, 3, 262-270. [CrossRef]

47. Semo, E.; Kesselman, E.; Danino, D.; Livney, Y.D. Casein micelle as a natural nano-capsular vehicle for nutraceuticals. Food Hydrocoll. 2007, 21, 936-942. [CrossRef]

48. DeRitter, E. Vitamins in pharmaceutical formulations. J. Pharm. Sci. 1982, 71, 1073-1096. [CrossRef]

49. Jafari, S.M.; Vakili, S.; Dehnad, D. Production of a functional yogurt powder fortified with nanoliposomal vitamin D through spray drying. Food Bioprocess Technol. 2019, 12, 1220-1231. [CrossRef]

50. Sharifan, P.; Khoshakhlagh, M.; Khorasanchi, Z.; Darroudi, S.; Rezaie, M.; Safarian, M.; Vatanparast, H.; Afshari, A.; Ferns, G.; Ghazizadeh, H.; et al. Efficacy of low-fat milk and yogurt fortified with encapsulated vitamin $\mathrm{D}_{3}$ on improvement in symptoms of insomnia and quality of life: Evidence from the SUVINA trial. Food Sci. Nutr. 2020, 8, 4484-4490. [CrossRef]

51. Leskauskaite, D.; Jasutiene, I.; Malinauskyte, E.; Kersiene, M.; Matusevicius, P. Fortification of dairy products with vitamin $D_{3}$. Int. J. Dairy Technol. 2016, 69, 177-183. [CrossRef]

52. Levinson, Y.; Ish-Shalom, S.; Segal, E.; Livney, Y.D. Bioavailability, rheology and sensory evaluation of fat-free yogurt enriched with $\mathrm{VD}_{3}$ encapsulated in re-assembled casein micelles. Food Funct. 2016, 7, 1477-1482. [CrossRef]

53. Kim, J.S.; Ahn, J.; Seok, J.S.; Kwak, H.S. Microencapsulated iron for drink yogurt fortification. Asian Australas. J. Anim. Sci. 2003, 16, 581-587. [CrossRef]

54. Mehansho, H. Iron fortification technology development: New approaches. J. Nutr. 2006, 136, 1059-1063. [CrossRef] [PubMed]

55. Gahrui, H.H.; Eskandari, M.H.; Mesbahi, G.; Hanifpour, M.A. Scientific and technical aspects of yogurt fortification: A review. Food Sci. Hum. Wellness 2015, 4, 1-8. [CrossRef]

56. Lane, D.J.R.; Richardson, D.R. The active role of vitamin C in mammalian iron metabolism: Much more than just enhanced iron absorption! Free Radic. Biol. Med. 2014, 75, 69-83. [CrossRef]

57. Nkhata, S.G.; Ustunol, Z.; Menevseoglu, A. Iron fortification of yogurt and pasteurized milk. J. Nutr. Health Food Sci. 2015, 3, 1-12. [CrossRef]

58. Gutierrez, G.; Matos, M.; Barrero, P.; Pando, D.; Iglesias, O.; Pazos, C. Iron-entrapped niosomes and their potential application for yogurt fortification. LWT Food Sci. Technol. 2017, 74, 550-556. [CrossRef]

59. Sani, I.K.; Khaledabad, M.A.; Pirsa, S.; Kia, E.M. Physico-chemical, organoleptic, antioxidative and release characteristics of flavoured yoghurt enriched with microencapsulated Mellisa officinalis essential oil. Int. J. Dairy Technol. 2020, 73, 542-551. [CrossRef]

60. Tita, O.; Constantinescu, M.A.; Tita, M.A.; Georgescu, C. Use of yoghurt enhanced with volatile plant oils encapsulated in sodium alginate to increase the human body's immunity in the present fight against stress. Int. J. Environ. Res. Public Health 2020, 17, 7588. [CrossRef]

61. Nazari, M.; Ghanbarzadeh, B.; Kafil, H.S.; Zeinali, M.; Hamishehkar, H. Garlic essential oil nanphytosomes as a natural preservative: Its application in yogurt as food model. Colloid Interface Sci. Commun. 2019, 30, 100176. [CrossRef]

62. Mishra, A.P.; Devkota, H.P.; Nigam, M.; Adetunji, C.O.; Srivastava, N.; Saklani, S.; Shukla, I.; Azmi, L.; Shariati, M.A.; Coutinho, H.D.M.; et al. Combination of essential oils in dairy products: A review of their functions and potential benefits. LWT Food Sci. Technol. 2020, 133, 110116. [CrossRef]

63. Troesch, B.; Eggersdorfer, M.; Laviano, A.; Rolland, Y.; Smith, A.D.; Warnke, I.; Weimann, A.; Calder, P.C. Expert opinion on benefits of long-chain omega-3 fatty acids (DHA and EPA) in aging and clinical nutrition. Nutrients 2020, 12, 2555. [CrossRef] [PubMed]

64. Bakry, A.M.; Chen, Y.Q.; Liang, L. Developing a mint yogurt enriched with omega-3 oil: Physicochemical, microbiological, rheological, and sensorial characteristics. J. Food Process. Preserv. 2019, 43, e14287. [CrossRef]

65. Jamshidi, A.; Shabanpour, B.; Pourashouri, P.; Raeisi, M. Optimization of encapsulation of fish protein hydrolysate and fish oil in $W_{1} / O / W_{2}$ double emulsion: Evaluation of sensory quality of fortified yogurt. J. Food Process. Preserv. 2019, 43, e14063. [CrossRef]

66. Ghorbanzade, T.; Jafari, S.M.; Akhavan, S.; Hadavi, R. Nano-encapsulation of fish oil in nano-liposomes and its application in fortification of yogurt. Food Chem. 2017, 216, 146-152. [CrossRef] [PubMed]

67. Tamjidi, F.; Nasipour, A.; Shahedi, M. Physicochemical and sensory properties of yogurt enriched with microencapsulated fish oil. Food Sci. Technol. Int. 2012, 18, 381-390. [CrossRef]

68. Liu, D.; Zhang, T.; Jiang, N.; Xi, C.; Sun, C.; Zheng, J.; Guo, M. Effects of encapsulated fish oil by polymerized whey protein on the textural and sensory characteristics of low-fat yogurt. Pol. J. Food Nutr. Sci. 2016, 66, 189-198. [CrossRef] 
69. Lerma-Garcia, M.; Herrero-Martinez, J.; Simó-Alfonso, E.; Mendonça, C.R.; Ramis-Ramos, G. Composition, industrial processing and applications of rice bran $\gamma$-oryzanol. Food Chem. 2009, 115, 389-404. [CrossRef]

70. Zhong, J.; Yang, R.; Cao, X.; Liu, X.; Qin, X. Improved physicochemical properties of yogurt fortified with fish oil/ $\gamma$-nanoemulsion technology. Molecules 2018, 23, 56. [CrossRef]

71. Lane, K.E.; Li, W.; Smith, C.; Derbyshire, E. The bioavailability of an omega-3 rich algal oil is improved by nanoemulsion technology using yogurt as a food vehicle. Int. J. Food Sci. Technol. 2014, 49, 1264-1271. [CrossRef]

72. Gharehcheshmeh, M.H.; Arianfar, A.; Mahdian, E.; Naji-Tabasi, S. production and evaluation of sweet almond and sesame oil mamoemulsion and their effects on physico-chemical, rheological and microbial characteristics of enriched yogurt. J. Food Meas. Charact. 2020. [CrossRef]

73. Comunian, T.A.; Chaves, I.E.; Thomazini, M.; Moraes, I.C.F.; Ferro-Furtado, R.; de Castro, I.A.; Favaro-Trindade, S.F. Development of functional yogurt containing free and encapsulated echium oil, phytosterol and sinapic acid. Food Chem. 2017, 237, 948-956. [CrossRef]

74. Afaro, L.; Hayes, D.; Boeneke, C.; Xu, Z.; Bankston, D.; Bechtel, P.J.; Sathivel, S. Physical properties of a frozen yogurt fortified with a nano-emulsion containing purple rice bran oil. LWT Food Sci. Technol. 2015, 62, 1184-1191. [CrossRef]

75. Abedi, A.-S.; Rismanchi, M.; Shahdoostkhany, M.; Mohammadi, A.; Hosseini, H. Microencapsulation of Nigella sativa seeds oil containing thymoquinone by spray-drying for functional yogurt production. Int. J. Food Sci. Technol. 2016, 51, 2280-2289. [CrossRef]

76. Tan, P.Y.; Tan, T.B.; Chang, H.W.; Tey, B.T.; Chan, E.S.; Lai, O.M.; Baharin, B.S.; Nehdi, I.A.; Tan, C.P. Effects of storage and yogurt matrix on the stability of tocotrienols encapsulated in chitosan-alginate microcapsules. Food Chem. 2018, 241, 79-85. [CrossRef] [PubMed]

77. Francisco, C.R.L.; Heleno, S.A.; Fernandes, I.P.M.; Barreira, J.C.M.; Calhelha, R.C.; Barros, L.; Goncalves, O.H.; Ferreira, I.C.F.R.; Barreiro, M.F. Functionalization of yogurts with Agaricus bisporus extracts encapsulated in spray-dried maltodextrin crosslinked with citric acid. Food Chem. 2018, 245, 845-853. [CrossRef] [PubMed]

78. Nourmohammadi, N.; Soleimanian-Zad, S.; Shekarchizadeh, H. Effect of Spirulina (Arthrospira platensis) microencapsulated in alginate and whey protein concentrate addition on physicochemical and organoleptic properties of functional stirred yogurt. $J$. Sci. Food Agric. 2020, 100, 5260-5268. [CrossRef]

79. Muthukumarasamy, P.; Allan-Wojtas, P.; Holley, R.A. Stability of Lactobacillus reuteri in different types of microcapsules. J. Food Sci. 2006, 71, M20-M24. [CrossRef]

80. Shah, N.P. Probiotic bacteria: Selective enumeration and survival in dairy foods. J. Dairy Sci. 2000, 83, 894-907. [CrossRef]

81. Picot, A.; Lacroix, C. Encapsulation of bifidobacterial in whey protein-based microcapsules and survival in simulated gastrointestinal conditions and in yoghurt. Int. Dairy J. 2004, 14, 505-515. [CrossRef]

82. Adhikari, K.; Mustapha, A.; Grun, I.U. Survival and metabolic activity of microencapsulated Bifidobacterium longum in stirred yogurt. J. Food Sci. 2003, 68, 275-280. [CrossRef]

83. Adhikari, K.; Mustapha, A.; Grun, I.U.; Fernando, L. Viability of microencapsulated bifidobacterial in set yogurt during refrigerated storage. J. Dairy Sci. 2000, 83, 1946-1951. [CrossRef]

84. Pinto, S.S.; Fritzen-Freire, C.B.; Dias, C.O.; Amboni, R.D.M.C. A potential technological application of probiotic microcapsules in lactose-free Greek-style yoghurt. Int. Dairy J. 2019, 97, 131-138. [CrossRef]

85. Pinto, S.S.; Cavalcante, B.D.M.; Verruck, S.; Alves, L.F.; Prudencio, E.S.; Amboni, R.D.M.C. Effect of the incorporation of Bifidobacterium BB-12 microencapsulated with sweet whey and inulin on the properties of Greek-style yogurt. J. Food Sci. Technol. 2017, 54, 2804-2813. [CrossRef]

86. Kia, E.M.; Ghasempour, Z.; Ghanbari, S.; Pirmohammadi, R.; Ehsani, A. Development of probiotic yogurt by incorporation of milk protein concentrate (MPC) and microencapsulated Lactobacillus paracasei in gellan-caseinate mixture. Br. Food J. 2018, 120, 1516-1528.

87. Shoji, A.S.; Oliveira, A.C.; Balieiro, J.C.C.; Freitas, O.; Thomazini, M.; Heinemann, R.J.B.; Okuro, P.K.; Favaro-Trindade, C.S. Viability of L. acidophilus microcapsules and their application to buffalo milk yoghurt. Food Bioprod. Process. 2013, 91, 83-88. [CrossRef]

88. Ribeiro, M.C.; Chaves, K.S.; Gebara, C.; Infante, F.N.S.; Grosso, C.R.F.; Gigante, M.L. Effect of microencapsulation of Lactobacillus acidophilus LA-5 on physicochemical, sensory and microbiological characteristics of stirred probiotic yoghurt. Food Res. Int. 2014, 66, 424-431. [CrossRef]

89. Krasaekoopt, W.; Bhandari, B.; Deeth, H.C. Survival of probiotics encapsulated in chitosan-coated alginate beads in yoghurt from UHT-and conventionally treated milk during storage. LWT Food Sci. Technol. 2006, 39, 177-183. [CrossRef]

90. Sandova-Castilla, O.; Lobato-Calleros, C.; Garsia-Galindo, H.S.; Alvarez-Ramirez, J.; Vernon-Carter, E.J. Textural properties of alginate-pectin beads and survivability of entrapped Lb. casei in simulated gastrointestinal conditions and in yoghurt. Food Res. Int. 2010, 43, 111-117. [CrossRef]

91. Yao, M.; Xie, J.; Du, H.; McClements, D.J.; Xiao, H.; Li, L. Progress in microencapsulation of probiotics: A review. Compr. Rev. Food Sci. Food Saf. 2020, 19, 857-874. [CrossRef]

92. Li, H.; Zhang, T.; Li, C.; Zheng, S.; Li, H.; Yu, J. Development of a microencapsulated synbiotic product and its application in yoghurt. LWT Food Sci. Technol. 2020, 122, 109033. [CrossRef] 
93. Li, C.; Wang, C.-L.; Li, A.-L.; Liu, F.; Meng, X.-C. Microencapsulation of Lactobacillus rhamnosus GG by transglutaminase cross-linked soy protein isolate to improve survival in simulated gastrointestinal conditions and yoghurt. J. Food Sci. 2016, 81, M1726-M1734. [CrossRef]

94. Aljouni, S.; Ranadheera, C.S.; Chua, E.L. Encapsulation increases the in vitro bioaccessibility of probiotics in yoghurt. Int. Dairy Technol. 2021, 74, 118-127.

95. Wszolek, M.; Kupiec-Teahan, B.; Skow Guldager, H.; Tamime, A.Y. Production of kefir, koumiss and other related products. In Fermented Milks, 1st ed.; Tamime, A., Ed.; Blackwell Science Ltd.: Oxford, UK, 2006; pp. 174-216.

96. Rosa, D.D.; Dias, M.M.S.; Grzeskowiak, L.M.; Reis, S.A.; Conceicao, L.L.; do Carmo, G.; Peluzio, M. Milk kefir: Nutritional, microbiological and health benefits. Nutr. Res. Rev. 2017, 30, 82-96. [CrossRef]

97. Yuksel-Bilsel, A.; Sahin-Yesilcubuk, N. Production of probiotic kefir fortified with encapsulated structured lipids and investigation of matrix effects by means of oxidation and in vitro digestion studies. Food Chem. 2019, 296, 17-22. [CrossRef]

98. Nielsen, B.; Gurakan, G.C.; Unlu, G. Kefir: A multifaced fermented dairy product. Probiotics Antimicrob. Proteins 2014, 6, 123-135. [CrossRef]

99. Gonzalez- Sanchez, F.; Azaola, A.; Gutierrez-Lopez, G.F.; Hernadez-Sanchez, H. Viability of microencapsulated Bifidobacterium animalis ssp. lactis BB12 in kefir during refrigerated storage. Int. J. Dairy Technol. 2010, 63, 431-436. [CrossRef]

100. Yilmaz, M.T.; Taylan, O.; Karakas, C.Y.; Dertli, E. An alternative way to encapsulate probiotics within electrospun alginate nanofibers as monitored under simulated gastrointestinal conditions and in kefir. Carbohydr. Polym. 2020, 244, 116447. [CrossRef]

101. Karimi, R.; Mortazavian, A.M.; Da Cruz, A.G. Viability of probiotic microorganisms in cheese during production and storage: A review. Dairy Sci. Technol. 2011, 91, 283-308. [CrossRef]

102. Ningtyas, D.W.; Bhandari, B.; Bansal, N.; Prakash, S. The viability of probiotic Lactobacillus rhamnosus (non-encapsulated and encapsulated) in functional reduced-fat cream cheese and its textural properties during storage. Food Control 2019, 100, 8-16. [CrossRef]

103. Liu, L.; Chen, P.; Zhao, W.; Li, X.; Wang, H.; Qu, X. Effect of microencapsulation with the Maillard reaction products of whey proteins and isomaltooligosaccharide on the survival rate of Lactobacillus rhamnosus in white brined cheese. Food Control 2017, 79, 44-49. [CrossRef]

104. Ozer, B.; Kirmaci, H.A.; Senel, E.; Atamer, M.; Hayaloglu, A. Improving the viability of Bifidobacterium bifidum BB-12 and Lactobacillus acidophilus LA-5 in white-brined cheese by microencapsulation. Int. Dairy J. 2009, 19, 22-29. [CrossRef]

105. Kia, E.M.; Alizadeh, M.; Esmaiili, M. Development and characterization of probiotic UF Feta cheese containing Lactobacillus paracasei microencapsulated by enzyme based gelation method. J. Food Sci. Technol. 2018, 55, 3657-3664.

106. Sharifi, S.; Rezazad-Bari, M.; Alizadeh, M.; Almasi, H. Use of whey protein isolate and gum Arabic for the co-encapsulation of probiotic Lactobacillus plantarum and phytosterols by complex coacervation: Enhanced viability of probiotic in Iranian white cheese. Food Hydrocoll. 2021, 113, 106496. [CrossRef]

107. Mirzaei, H.; Pourjafar, H.; Homayouni, A. Effect of calcium alginate and resistant starch microencapsulation on the survival rate of Lactobacillus acidophilus La5 and sensory properties in Iranian white brined cheese. Food Chem. 2012, 132, 1966-1970. [CrossRef]

108. Zomorodi, S.; Asl, A.K.; Rohani, S.M.R.; Miraghaei, S. Survival of Lactobacillus casei, Lactobacillus plantarum and Bifidobacterium bifidum in free and microencapsulated forms on Iranian white cheese produced by ultrafiltration. Int. J. Dairy Technol. 2011, 64, 84-91. [CrossRef]

109. Afzaal, M.; Saeed, F.; Ateeq, H.; Ahmed, A.; Ahmad, A.; Tufail, T.; Ismail, Z.; Anjum, F.M. Encapsulation of Bifidobacterium bifidum by internal gelation method to access the viability in cheddar cheese and under simulated gastrointestinal conditions. Food Sci. Nutr. 2020, 8, 2739-2747. [CrossRef] [PubMed]

110. Amine, K.M.; Champagne, C.P.; Raymond, Y.; St-Gelais, D.; Britten, M.; Fustier, P.; Salmieri, S.; Lacroix, M. Survival of microencapsulated Bifidobacterium longum in Cheddar cheese during production and storage. Food Control 2014, 37, 193-199. [CrossRef]

111. Abd-Elhamid, A.M. Production of functional Kariesh cheese by microencapsulation of Bifidobacterium adolescentis ATCC 15704 . Adv. J. Food Sci. Technol. 2012, 4, 112-117.

112. Ortakci, F.; Broadbent, J.R.; McManus, W.R.; McMahon, D.J. Survival of microencapsulated probiotic Lactobacillus paracasei durinf manufacture of Mozzarella cheese and simulated gastric digestion. J. Dairy Sci. 2012, 95, 6274-6281. [CrossRef] [PubMed]

113. Radulovic, Z.; Miocinovic, J.; Mirkovic, N.; Mirkovic, M.; Paunovic, D.; Ivanivic, M.; Seratlic, S. Survival of spray-dried and free-cells of potential probiotic Lactobacillus plantarum 564 in soft goat cheese. Anim. Sci. J. 2017, 88, 1849-1854. [CrossRef]

114. Haratifar, S.; Corredig, M. Interactions between tea catechins and casein micelles and the impact on renneting functionality. Food Chem. 2014, 143, 27-32. [CrossRef] [PubMed]

115. Ribeiro, A.; Caleja, C.; Barros, L.; Santos-Buelga, C.; Barreiro, F.; Ferreira, I.C.F.R. Rosemary extracts in functional foods: Extraction, chemical characterization and incorporation of free and microencapsulated forms in cottage cheese. Food Funct. 2016, 7, 2185-2196. [CrossRef] [PubMed]

116. Caleja, C.; Ribeiro, A.; Barros, L.; Barreira, J.C.M.; Antonio, A.L.; Oliveira, M.B.P.P.; Barreiro, M.F.; Ferreira, I.C.F.R. Cottage cheeses functionalized with fennel and chamomile extracts: Comparative performance between free and microencapsulated forms. Food Chem. 2016, 199, 720-726. [CrossRef] [PubMed] 
117. Rashidinejad, A.; Birch, E.J.; Sun-Waterhouse, D.; Everett, D.W. Delivery of green tea catechin and epigallocatechin gallate in liposomes incorporated into low-fat hard cheese. Food Chem. 2014, 156, 176-183. [CrossRef] [PubMed]

118. Rashidinejad, A.; Birch, E.J.; Everett, D.W. A novel functional full-fat hard cheese containing liposomal nanoencapsulated green tea catechins: Manufacture and recovery following simulated digestion. Food Funct. 2016, 7, 3283-3294. [CrossRef] [PubMed]

119. Rashidinejad, A.; Birch, E.J.; Sun-Waterhouse, D.; Everett, D.W. Effect of liposomal encapsulation on the recovery and antioxidant properties of gree tea catechins incorporated into a hard low-fat cheese following in vitro simulated gastrointestinal digestion. Food Bioprod. Process. 2016, 100, 238-245. [CrossRef]

120. Farrag, A.F.; Zahran, H.A.; Al-Okbay, M.F.; El-Sheikh, M.M.; Soliman, T.N. Physicochemical properties of white soft cheese supplemented with encapsulated olive phenolic compounds. Egypt. J. Chem. 2020, 63, 2921-2931. [CrossRef]

121. Pereira, A.B.; da Silva, A.M.; Barroca, M.J.; Marques, M.P.M.; Braga, S.S. Physicochemical properties, antioxidant action and practical application in frech cheese of the solid inclusion compound $\gamma$-cyclodextrin ·quercetin, in comparison with $\beta$-cyclodextrin - quercetin. Arab. J. Chem. 2020, 13, 205-215. [CrossRef]

122. Sharma, P.; Segat, A.; Kelly, A.L.; Sheehan, J.J. Colorants in cheese manufacture: Production, chemistry, interactions, and regulation. Compr. Rev. Food Sci. Food Saf. 2020, 19, 1220-1242. [CrossRef] [PubMed]

123. Kwak, H.-S.; Chimed, C.; Yoo, S.-H.; Chang, Y.H. Physicochemical and sensory properties of Appenzeller cheese supplemented with powdered microcapsule of tomato extract during ripening. Korean J. Food Sci. Anim. Resour. 2016, 36, 244-253. [CrossRef] [PubMed]

124. Jeong, H.-J.; Lee, Y.-K.; Ganesan, P.; Kwak, H.-S.; Chang, Y.H. Physicochemical, microbial, and sensory properties of Queso Blanco cheese supplemented with powdered microcapsules of tomato extracts. Korean J. Food Sci. Anim. Resour. 2017, 37, 342-350. [CrossRef]

125. Balabanova, T.; Petkova, N.; Ivanova, M.; Panayotov, N. Design of Labneh cheese fortified with alginate-encapsulated pepper (Capsicum annuum) extracts. Emir. J. Food Agric. 2020, 32, 559-566. [CrossRef]

126. Smith, T.J.; Li, X.E.; Drake, M.A. Short communication: Norbixin and bixin partitioning in Cheddar cheese and whey. J. Dairy Sci. 2014, 97, 3321-3327. [CrossRef] [PubMed]

127. Zhang, Y.; Zhong, Q. Encapsulation of bixin in sodium caseinate to deliver the colorant in transparent dispersions. Food Hydrocoll. 2013, 33, 1-9. [CrossRef]

128. Celli, G.B.; Lawrence, P.; Ravanfar, R.; Abbaspourrad, A. Solvent-mediated pressure-treated bixin-casein complexation for targeted color delivery. Food Chem. 2019, 278, 434-442. [CrossRef]

129. Celli, G.B.; Ravanfar, R.; Kaliappan, S.; Kapoor, R.; Abbaspourrad, A. Annatto-entrapped casein-chitosan complexes improve whey color quality after acid coagulation of milk. Food Chem. 2018, 255, 268-274. [CrossRef]

130. Ravanfar, R.; Celli, G.B.; Abbaspourrad, A. Controlling the release from enzyme -responsive microcapsules with a smart natural shell. ACS Appl. Mater. Interfaces 2018, 10, 6046-6053. [CrossRef]

131. Munoz-Tebar, N.; De La Vara, J.A.; De Elguea-Culebras, G.O.; Cano, E.L.; Molina, A.; Carmona, M.; Berruga, M.I. Enrichment of sheep cheese with chia (Salvia hispanica L.) oil as a source of omega-3. LWT Food Sci. Technol. 2019, 108, 407-415. [CrossRef]

132. Leong, T.S.H.; Ong, L.; Gamlath, C.J.; Gras, S.L.; Ashokkumar, M.; Martin, G.J.O. Formation of cheddar cheese analogues using canola oil and ultrasonication-A comparison between single and double emulsion systems. Int. Dairy J. 2020, 105, 104683. [CrossRef]

133. Calligaris, S.; Ignat, A.; Biasutti, M.; Innocente, N.; Nicoli, M.C. Cheese fortification using saturated monoglyceride self-assembly structures as carrier of omega-3 fatty acids. Int. J. Food Sci. Technol. 2015, 50, 2129-2134. [CrossRef]

134. Stratulat, I.; Britten, M.; Salmieri, S.; Fustier, P.; St-Gelais, D.; Champagne, C.P.; Lacroix, M. Enrichment of cheese with vitamin $D_{3}$ and vegetable omega-3. J. Funct. Foods 2015, 13, 300-307. [CrossRef]

135. Banville, C.; Vuillemard, J.C.; Lacroix, M. Comparison of different methods for fortifying Cheddar cheese with vitamin D. Int. Dairy J. 2000, 10, 375-382. [CrossRef]

136. Stratulat, I.; Britten, M.; Salmieri, S.; St-Gelais, D.; Champagne, C.P.; Fustier, P.; Lacroix, M. Encapsulation of coenzyme $Q_{10}$ in a simple emulsion-based nutraceutical formulation and application in cheese manufacturing. Food Chem. 2013, 141, $2707-2712$. [CrossRef] [PubMed]

137. Stratulat, I.; Britten, M.; Salmieri, S.; Fustier, P.; St-Gelais, D.; Champagne, C.P.; Lacroix, M. Enrichment of cheese with bioactive lipophilic compounds. J. Funct. Foods 2014, 6, 48-59. [CrossRef]

138. Giroux, H.J.; Constantineau, S.; Fustier, P.; Champagne, C.P.; St-Gelais, D.; Lacroix, M.; Britten, M. Cheese fortification using water-in-oil-in- water double emulsions as a carrier for water soluble nutrients. Int. Dairy J. 2013, 29, 107-114. [CrossRef]

139. Arce, A.; Ustunol, Z. Effect of microencapsulated ferrous sulfate particle size on Cheddar cheese composition and quality. J. Dairy Sci. 2018, 101, 6814-6822. [CrossRef]

140. De Melo, A.M.; Barbi, R.C.T.; de Souza, W.F.C.; Luna, L.C.; de Souza, H.J.B.; Lucena, G.L.; Quirino, M.R.; de Sousa, S. Microencapsulated lemongrass (Cymbopogon flexuosus) essential oil: A new source of natural additive applied to Coalho cheese. J. Food Process. Preserv. 2020, 44, e14783.

141. De Barros Fernandes, R.V.; Guimaraes, I.C.; Ferreira, C.L.R.; Botrel, D.A.; Borges, S.V.; de Souza, A.U. Microencapsulated rosemary (Rosmarinus officinalis) essential oil as a biopreservative in Minas frescal cheese. J. Food Process. Preserv. 2017, 41, e12759. [CrossRef] 